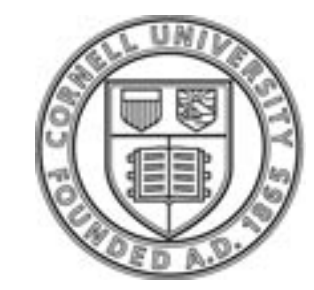

an application of risk contingent credit applied New York dairy farmers with U.S. options on class III milk futures

by $\mathrm{Cao} \mathrm{Yu}$

This thesis/dissertation document has been electronically approved by the following individuals:

Turvey,Calum G. (Chairperson)

Knoblauch,Wayne Alan (Minor Member) 


\title{
AN APPLICATION OF RISK CONTINGENT CREDIT APPLIED TO NEW YORK DAIRY FARMS WITH U.S. OPTIONS ON CLASS III MILK FUTURES
}

\author{
A Thesis \\ Presented to the Faculty of the Graduate School \\ of Cornell University \\ In Partial Fulfillment of the Requirements for the Degree of \\ Master of Science
}

by

$\mathrm{Cao} \mathrm{Yu}$

August 2010 
(C) $2010 \mathrm{Cao} \mathrm{Yu}$ 


\begin{abstract}
The present day realities facing New York dairy farmers and all dairy farmers is an example of when business risk become so severe that the residual impact on financial risk become acute. While financial risk is ever present, stress results only when conditions arise in which downside risk result in a return on assets insufficient to meet fixed financial obligations.

Thus, it is proposed in this paper the use of commodity linked credit to balance financial and business risks faced by New York dairy farmers. In this paper, commodity linked credit refers to a suite of financial products in the form of operating loan and mortgage with payoff schedules tied to the price of class III milk futures price.
\end{abstract}

To apply commodity linked credit, a represent farm financial statement is established and modified. Monte Carlo simulation is then used to analysis the effect of commodity linked credit.

By comparing return on assets (ROA), return on equity (ROE) and other financial parameters before and after implementing commodity linked operating loan and mortgage, conclusion is reached that commodity linked credit is a proven method to hedge business risk and financial risk. 


\section{BIOGRAPHICAL SKETCH}

Cao Yu was born in 1986 in China. She is the only child in her family. At the age of 1 , she moved to Beijing with her parents and started her exciting urban life. She finished her junior and senior high school at the high school affiliated to Renmin University of China.

Afterwards, Cao was matriculated by Tsinghua University in Beijing. Majoring in Biology and Biotechnology, she graduated from Tsinghua University in July of 2008. She decided to pursuit higher education in finance and economics abroad after several internships in the financial industry during her college years.

Cao began her study at Department of Applied Economics and Management in Cornell University in the fall of 2008. 
Delicate to Dairy Farmers in New York State and to My Parents 


\section{ACKNOWLEDGMENTS}

I owed my thanks to many people and would like to use this chance to show my gratitude. First and foremost, a big thanks to my advisor professor Calum Turvey for the energy and time he has spend on me. I appreciate his guidance and patience in me while I solicited him with numerous questions. I would also like to thank my committee member professor Wayne Knoblauch for all his great suggestions while writing this thesis. The administrative staff, Linda Morehouse has helped me in many ways during these two years in AEM.

I would like to thank my parents for their belief in me. I could not imagine pursuit my master's degree abroad without their care. They have been the inspiration for me. My friends Jing Ning, Jing Guo and Hans Chua have encouraged and accompanied me to go through a tough time; they made my stay in Ithaca fun and colorful. Nan Lin had been kind enough to agree to lend her laptop to me. Wei Wang and Frank Liu have been very responsible and quick to help me on formatting this thesis. Finally, I would love to give my special thanks to David Fan and his parents for taking care of me and making me felt at home in the US. Again, thank you to those I have mentioned and those I may have forgotten. 
TABLE OF CONTENTS

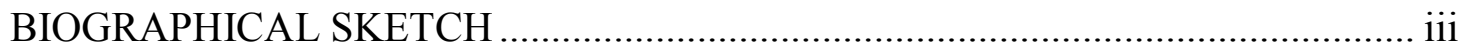

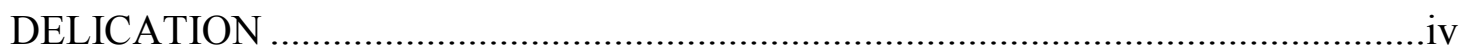

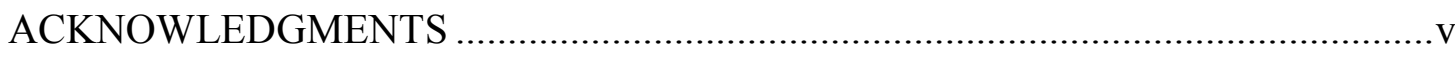

TABLE OF CONTENTS .....................................................................................

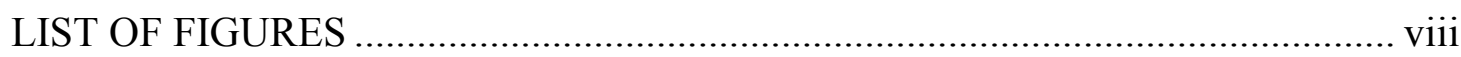

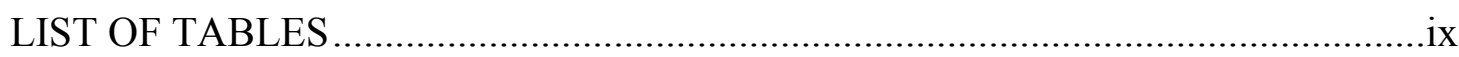

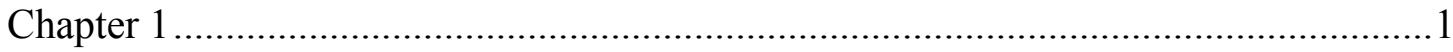

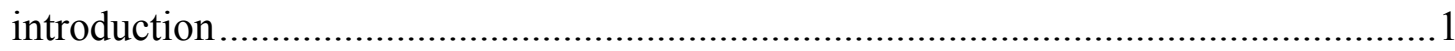

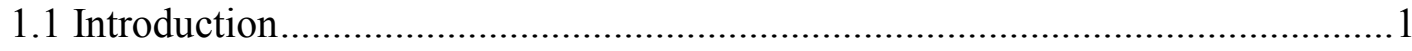

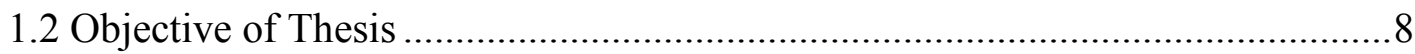

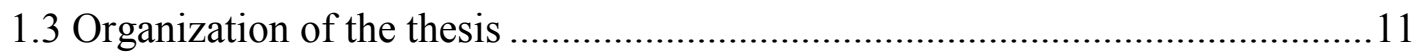

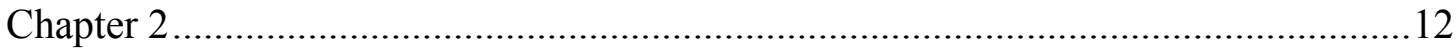

theoretical framework

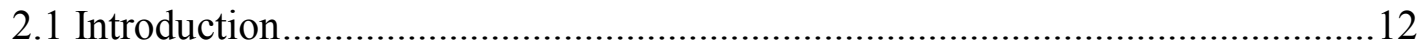

2.2 The mechanism of commodity linked credit ................................................12

2.3 Financial risk, business risk, hedging ratio and leverage ratio ...........................14

2.4 Credit constraints and the economics of production..........................................19

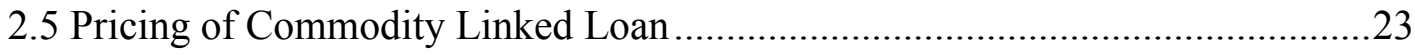

2.6 Pricing Commodity Linked Mortgage ................................................................26

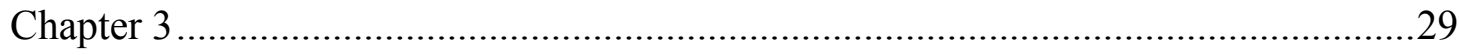

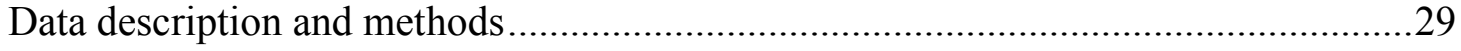

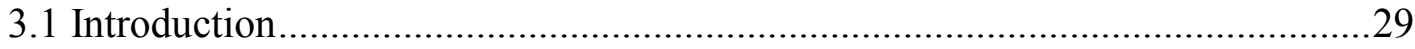

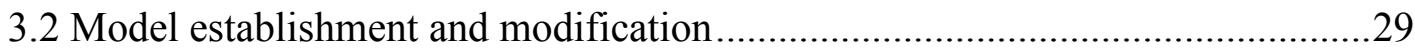

3.3 Other data sources and assumptions ..............................................................4

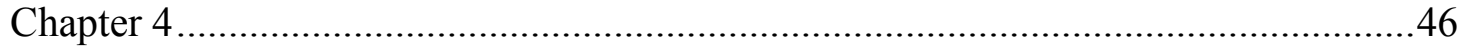

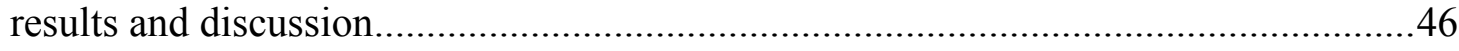

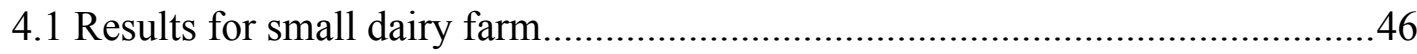

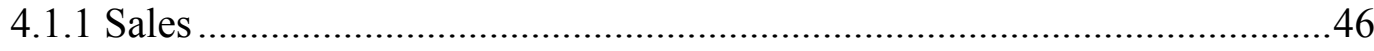

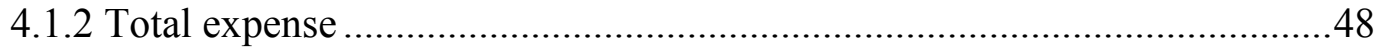

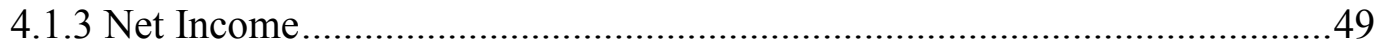

4.1.4 Debt coverage ratio versus option payout..................................................51

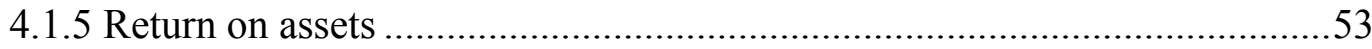




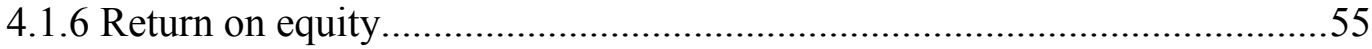

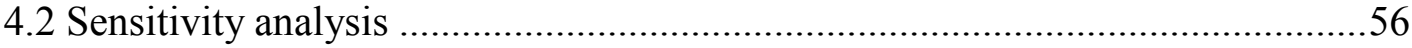

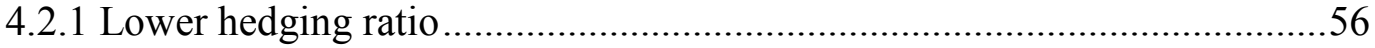

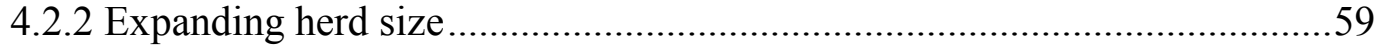

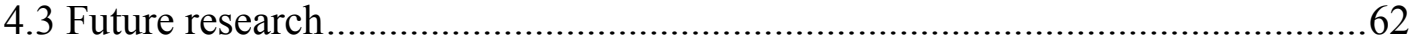

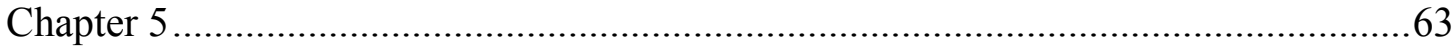

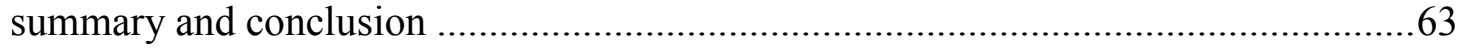

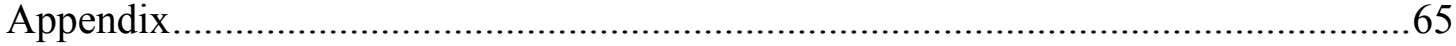




\section{LIST OF FIGURES}

Figure 1 New York Dairy Farm Size Trend from 1992 to 2007 .................................

Figure 2 New York Monthly All Milk Price, Jan 2000 to Feb 2010 ............................4

Figure 3 Trend In Milk Price, Debt Coverage Ratio and Leverage Ratio From 2003 to 2008 7

Figure 4 Payoff of Commodity Linked Credit....................................................... 10

Figure 5 Principal Repayment of Commodity Linked Loan for Borrowers ................ 14

Figure 6 Cash Flow of Commodity Linked Mortgage For Lenders ............................26

Figure 7 Monthly Class III Milk Futures and Spot Price, NY All Milk Price

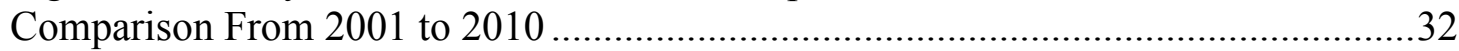

Figure 8 Crop Land Value per Acre by State 2009 ................................................45

Figure 9 Sales Distribution of Base Model and with CLM ....................................46

Figure 10 Sales Distribution for Base and CLO ........................................................47

Figure 11 Total Expense Distribution of Base and CLM ..........................................48

Figure 12 Total Expense Distribution of Base and CLO ..........................................48

Figure 13 Distribution of Net Income for Base and CLM..........................................49

Figure 14 Distribution of Net Income for Base and CLO ......................................50

Figure 15 Debt Coverage Ratio vs. Option Payouts for CLM...................................51

Figure 16 Debt Coverage Ratio vs. Option Payouts for CLO ..................................52

Figure 17 Cumulative Distribution of ROA for Base Farm and Farm with CLM .......54

Figure 18 Cumulative Distribution of ROA for Base Farm and Farm with CLO ........54

Figure 19 Distribution of ROE for Base Farm and Farm with CLM ........................55

Figure 20 Distribution of ROE for Base Farm and Farm with CLO .........................55

Figure 21 Cumulative Distribution of Net Income for Base, CLM and CLO with 80\%

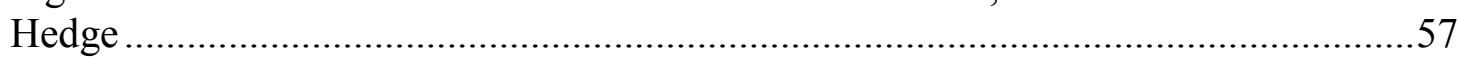

Figure 22 Cumulative Distribution of Sales for Base and with CLM, 80\% Hedge .....58

Figure 23 Cumulative Distribution of Sales for Base and with CLO, 80\% Hedge ......58

Figure 24 Option Payout vs. Debt Coverage Ratio of CLM for Herd Size of 150,......59

Figure 25 Option Payout vs. Debt Coverage Ratio of CLO for Herd Size of 150 ......60

Figure 26 Distribution of Net Income for Base Model and CLM, 150 Cows .............60

Figure 27 Distribution of Net Income for Base Model and CLO, 150 Cows...............61

Figure 28 CBOE Implied Volatility Calculator ....................................................65 


\section{LIST OF TABLES}

Table 1 Same 41 NY Dairy Farm Production Fact......................................................

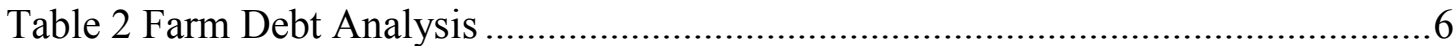

Table 3 Regression Result of NY All Milk Price on Futures Price................................33

Table 4 Correlation Coefficient Matrix for Soybean, Class III Milk and Corn Price ..36

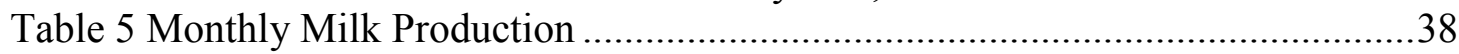

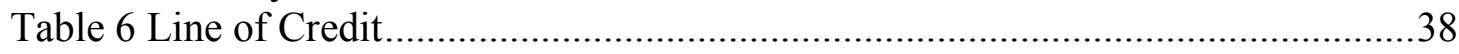

Table 7 Pricing of Option for Commodity Linked Loan ................................................40

Table 8 Commodity Linked Operating Loan Payment Schedule ...................................40

Table 9 Pricing of Option for Commodity Linked Mortgage..........................................42

Table 10 Interest Rate Calculation for Commodity Linked Mortgage ..........................42

Table 11 Comparison of Repayment Schedule for Normal Mortgage and CLM.........43

Table 12 Comparison of New York All Milk Prices, Class III Milk Futures Prices and

Calculated Class III Prices .........................................................................................66 


\section{LIST OF ABBREVIATIONS}

NASS

USDA

CLM

CLO

CME

CBOE
National Agricultural Statistics Service

United State Department Of Agriculture

Commodity Linked Mortgage

Commodity Linked Operating Loan

Chicago Mercantile Exchange

Chicago Board Options Exchange 


\section{Chapter 1}

\section{INTRODUCTION}

\subsection{Introduction}

Dairy farmers in New York State face volatilities not only in the prices they receive for milk production, but also in the cost of feeds and other inputs they used to produce milk. In 2009, following the aftermath of financial crisis, dairy farmers faced one of the worst low price situations in history. Dairy farm net income was squeezed and many were unable to meet their debt obligation. The situation has been such an ordeal that there have been media reports of cases of suicides among distressed dairy farmers because of their indebtedness.

The present day realities facing New York dairy farmers and all dairy farmers is an example of when business risk become so severe that the residual impact on financial risk become acute. While financial risk is ever present, stress results only when conditions arise in which downside risk result in a return on assets insufficient to meet fixed financial obligations.

Balancing business and financial risks has been the subject of much with the general argument that any reduction in business risk using crop insurance or market futures and options can encourage increased use of debt. In fact, Turvey and Baker (1989) argued that the optimum hedging ratio should rise and fall as debt to assets rise and fall. In other words, because futures or options payments provide a needed source of liquidity at the precise time that financial risk become acute, market risk management strategies should not be made in isolation of credit strategies. This thesis takes these ideas a step further by introduction the concept of risk contingent credit to New York dairy problem. 
In this context, risk contingent credit refers to operating or term credit with a payoff structure that is tied explicit to the source of an underlying business risk, in our case the class III milk price.

To place the problem and proposed solution in the context of New York dairy farmers, some background introduction about New York dairy industry is required. According to New York State Department of Agriculture \& Markets, milk is New York's leading agricultural product, milk sales account for one-half of total agricultural receipts. As the $3^{\text {rd }}$ leading producer nationwide, production in 2008 was 12.4 billion pounds with a value of $\$ 2.3$ billion. Thus, assisting existing and prospective dairy farmers to manage their risks will greatly contribute to stabilizing the large dairy industry in New York State.

The dairy industry in recent years is characterized by increasing economic of scale and high price volatilities. At the national level, data from USDA shows that approximately 4 to 7 percent of dairy operations have gone out of business each year since 1991 . The number of dairy operations has decreased by $58.4 \%$ since 1991 . Also, milk cow numbers were $93.8 \%$ of that of 1992 . As for New York State, Census of Agriculture shows that the number of dairy farms from 1992 to 2007 has been shrinking by nearly a half, from 10,696 to 5,683. As shown in Figure 1, most dairy farms that went out of business are small dairy farms with milk cow herd size smaller than 100 . However, there is substantial growth in large herd dairy farms with milk cow herd size greater than 500 increasing from 52 to 216 , a threefold increase. 


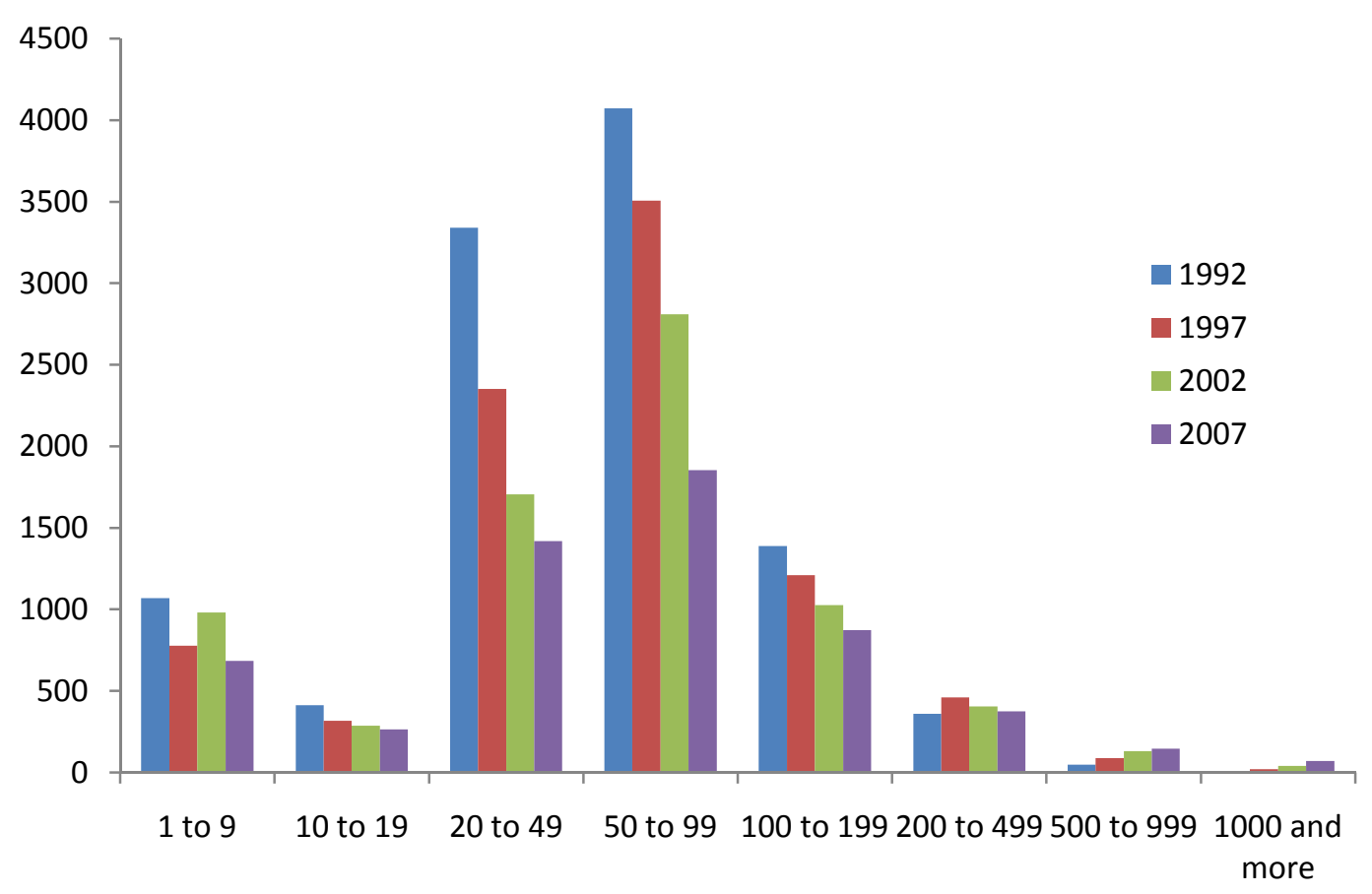

Figure 1 New York Dairy Farm Size Trend from 1992 to 2007

Thus, it will be argued that increased access to credit for dairy farmers to invest in capital as well as working capitals and their ability to preserve fixed assets from collateral requirements will help farmers reach economies of scale and have significant values to farmers.

Milk price faced by New York farmers have been quite volatile in recent years. As shown in Figure 2, monthly all milk prices ${ }^{1}$ received by New York State dairy farmers have encountered drastic up and downs during the 10 years period from 2000 to 2010 . The mean of all milk prices is $\$ 15.25 / \mathrm{cwt}$ and the standard deviation is 2.83

\footnotetext{
${ }^{1}$ According to California Department of Food and Agriculture, all milk price is defined as a weighted average of the prices dairy processors pay for all grade A and grade B milk, calculated by the NASS and usually reported for milk of average fat test
} 
during the 120 month period; the highest price is $\$ 22.8 /$ cwt, reached in September 2007, the price hit the bottom in March 2009 to $\$ 11.2 /$ cwt.

\section{New York State All Milk Price}

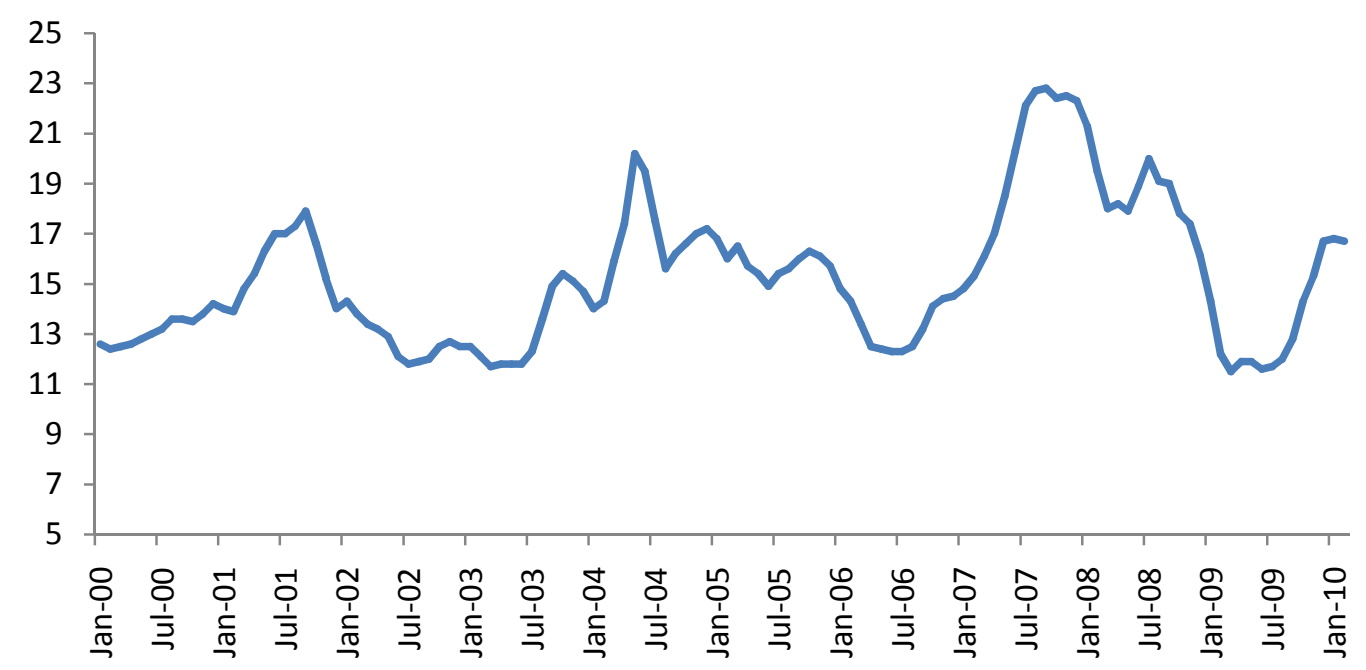

Figure 2 New York Monthly All Milk Price, Jan 2000 to Feb 2010

To get a glimpse of the effect of such price risks on New York dairy farmers, simply by comparing data from the Business Summary of New York State 2009 with that of 2008 shows that $60 \%$ of the 41 New York dairy farms with 100 or more cows surveyed generated negative net income (adjusted for inflation) in 2009 , with the $20 \%$ worst hit ones losing on average $\$ 781,694$. In 2009, the average net farm income without appreciation was $\$-144,714$, a sharp decline from 2008, when the same 41 dairy farms generate an average of $\$ 544,151$ of net income. Decreasing profitability also adversely affected the solvency abilities of these farms, with debt coverage ratio declining from 2.00 in 2008 to 0.21 in 2009 ; this means that in 2009 , for every dollar of scheduled repayments, dairy farmers, through the earnings of their businesses, are \$0.79 short. As shown in Table 1, even though dairy farmers effectively improved their cost management, e.g. both operating and administrating costs declined from 
2008 to 2009, a decline in net milk price from \$18.37 in 2008 to $\$ 13.09$ in 2009 was uncompromising, smaller sized dairy farmers who lack cost advantages may face even greater obstacles.

Table 1 Same 41 NY Dairy Farm Production Fact

\begin{tabular}{|l|r|r|}
\hline & 2008 & 2009 \\
\hline grain \& concentrate per cwt.milk & 5.67 & 5.16 \\
\hline grain \& concentrate purchased as \% of milk sales & $30 \%$ & $37 \%$ \\
\hline dairy feed \& crop expense per cwt.milk & 6.98 & 6.38 \\
\hline labor \& machinery costs per cow & 1506 & 1360 \\
\hline Purchased input cost of production cwt. Of milk & 16.02 & 14.74 \\
\hline total cost of production cwt. Of milk & 17.98 & 16.58 \\
\hline operating cost of production cwt. Of milk & 14.61 & 13.39 \\
\hline net milk price & 18.37 & 13.09 \\
\hline debt coverage ratio & 2.00 & 0.21 \\
\hline net farm income & $\$ 544,151$ & $\$-144,714$ \\
\hline
\end{tabular}

To get a clear picture of how low milk price affect the risk of NY dairy farmers, a basic financial statement analysis is conducted using data from Dariy Business Summary 2003-2008 for typical dairy farmers in NY state, which are summarized in Table 2. The main sources of debts of dairy farmers are account payable, current \& intermediate liabilities (including operating loans, short term and intermediate term debts) and long-term liabilities. These debts as percentage of total debts are stable at around $4 \%, 38 \%$ and $62 \%$ respectively.

One important conclusion from Table 2 is that when business risks, which is defined as price volatility in this setting increase, the financial risks (measured by debt coverage ratio and leverage ratio) increases too. Figure 3 shows how milk price, debt coverage ratio and leverage ratio move each year. 
Table 2 Farm Debt Analysis

\begin{tabular}{|c|c|c|c|c|c|c|c|}
\hline & 2002 & 2003 & 2004 & 2005 & 2006 & 2007 & 2008 \\
\hline Milk Price & 13 & 13.2 & 16.6 & 16.7 & 13.9 & 20.3 & 19.2 \\
\hline Leverage Ratio & 0.75 & 0.8 & 0.67 & 0.58 & 0.61 & 0.47 & 0.48 \\
\hline Long-term Liabilities as \% of Total Debt & $35 \%$ & $37 \%$ & $39 \%$ & $39 \%$ & $37 \%$ & $39 \%$ & $39 \%$ \\
\hline Current \& intermediate Liabilities as \% of Total Debt & $65 \%$ & $63 \%$ & $61 \%$ & $61 \%$ & $63 \%$ & $61 \%$ & $61 \%$ \\
\hline Cost of Term Debt & $4.70 \%$ & $4.50 \%$ & $4.90 \%$ & $5.60 \%$ & $6.30 \%$ & $6.20 \%$ & $4.80 \%$ \\
\hline long term debt repayment & 46,721 & 50,111 & 49,013 & 46,770 & 53,300 & 77,897 & 66,242 \\
\hline intermediate & 99,885 & 96,887 & 100,102 & 111,191 & 120,129 & 147,536 & 141,059 \\
\hline short term & 4,118 & 2,445 & 3,455 & 1,927 & 2,153 & 9,141 & 5,341 \\
\hline Operating & 5,261 & 10,680 & 4,902 & 4,748 & 6,557 & 22,078 & 11,993 \\
\hline account payable & 231 & 4,088 & 1,472 & 1,657 & 670 & 24,169 & 2,859 \\
\hline total debt repayment & 156,216 & 164,211 & 158,944 & 166,294 & 182,809 & 280,821 & 227,494 \\
\hline debt coverage ratio & 0.70 & 0.75 & 1.83 & 1.72 & 0.85 & 2.86 & 1.46 \\
\hline
\end{tabular}




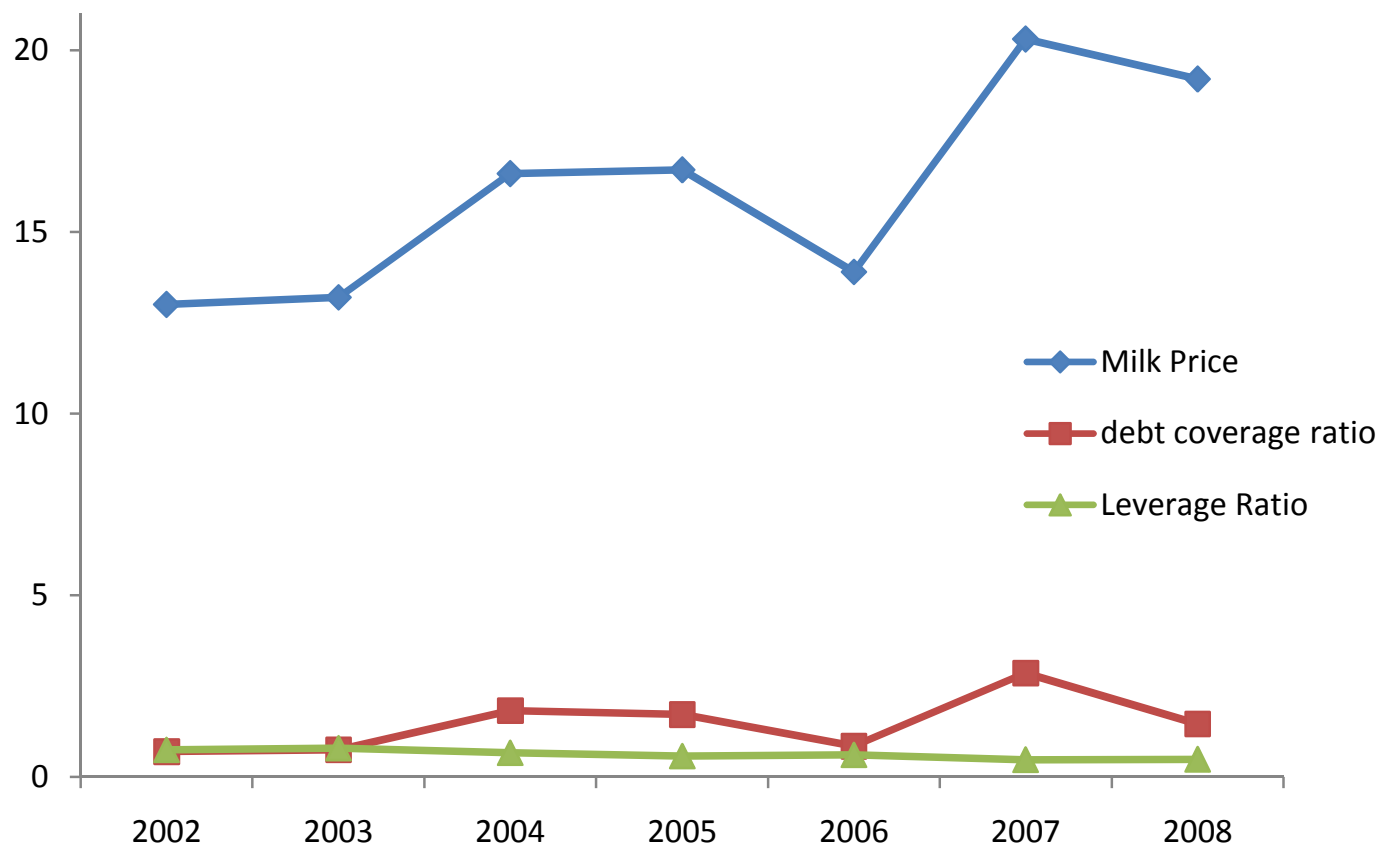

Figure 3 Trend In Milk Price, Debt Coverage Ratio and Leverage Ratio From 2003 to 2008

Clearly, when milk prices are high, the debt repayment abilities are high; when milk prices are low, as in 2003 and 2006, the debt repayment abilities decreased correspondingly; the debt coverage ratio fell below the benchmark of 1 , hitting 0.83 and 0.86 in 2003 and 2005; the leverage ratio in these two years are also higher than when the milk prices are high. The correlation between milk price and leverage ratio is -0.89 ; the correlation between milk price and the debt coverage ratio is 0.88 .

As demonstrated above, due to price fluctuation, dairy farmers face not only increased business risk but also financial risks, which will diminish the long term viability of dairy farms. Business risk for dairy farmers involves high volatility in dairy product prices and dairy producer milk prices. Such risks are extremely difficult for dairy producers, milk processors, and end users of milk and dairy products to manage and expose them to extreme downside risks in price. Increased price 
volatilities also increase the uncertainty of cash flow to the point where many dairy farmers delay investment in capital or any potential project even with positive NPV ${ }^{2}$. As milk prices decline, dairy farmers' abilities to repay loans decrease which leads to higher default risks. Faced with these risks, lenders have little choice but to ration credit to farmers or increase interest rate to compensate for the additional risk. Alternatively, lenders may require farmers to provide more collateral, be it farmland or essential capitals, which will restrain farmers' ability to leverage those assets and re-invest in production.

To analyze the use of the financial product proposed in this paper, several other important observations are made in the annual New York State Dairy Farm Business Summary,(Wayne Knoblauch and Linda Putnam provided detailed data of situations for New York State dairy farmers).(1) Nearly 50\% of the dairy farm business entities are in the form of sole proprietorship; (2) operators for dairy farms have 13 years of education and age is in the 50s on average; (3) the profitability for dairy farms declines as leverage increases; the leverage ratio of top $10 \%$ firms with the highest ROA is 0.4 , which is lower than the average leverage ratio of 0.47 . This third observation is not trivial. On the surface it suggests that on-farm leverage investments have a return that is less than the cost of debt capital. This is likely due to mismanaged risk. This persuades us that reducing the price risks faced by NY dairy farmers have significant meanings since an adverse price movement will affect not only their business but also their personal livelihood.

\subsection{Objective of Thesis}

Given an environment in which dairy farmers must borrow to maintain operations or make new investments under conditions of price uncertainty, the real

\footnotetext{
${ }^{2} \mathrm{NPV}$ is the net present value of a project. It is calculated by discounting all future expected cash flow to present and subtract the investment cash outflow today
} 
challenge faced is in how business and financial risk can be balanced. This is the problem addressed in this thesis. The overall objective of this paper is to provide solutions to these problems through the design and application of risk-contingent credit. In this context, risk contingency credit refers to a suite of financial products with payoff schedules (loan principal) that are tied to the price of an underlying commodity. In this case the underlying price risk is class III milk, which is traded as futures and options at Chicago Mercantile Exchange (CME) and is established as the base price for milk sold in New York. Thus, commodity-linked credit is a structured financial product in the form of an operating loan or mortgage with repayment tied to the underlying price of milk.

To briefly place this in context, consider a dairy farmer who borrowed an operating commodity linked loan with repayment tied to the milk price at maturity from a financial institution in 2008. A year later, when the loan matures in 2009, if the milk price rise above the stated price (contracted when starting the loan), the dairy farmer will repay the full principal amount; however, if milk price declines below the stated price, the dairy farmer will repay the principal minus a prorated difference between stated price and the actual milk price. In this way, the dairy farmer is protected against downside milk prices. As for the financial institution who issued the loan, their payoff does not change because the differences will be paid by the imbedded put option. The payoff structure is shown in Figure 4. In essence, the imbedded derivatives against price fluctuation in the commodity-linked loan mitigate financial and business risks of dairy farmers and help them survive the current economic downturns. 


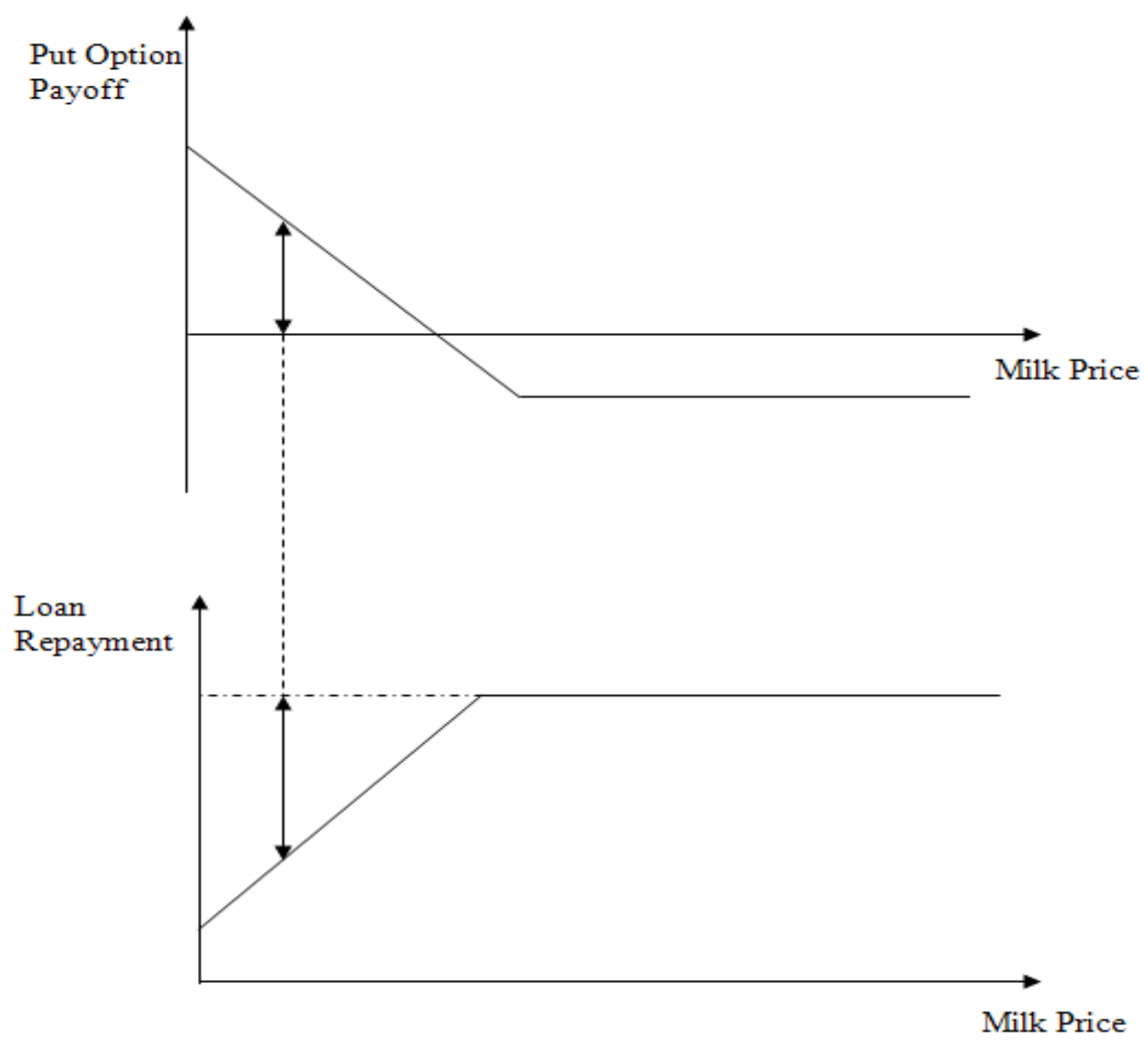

Figure 4 Payoff of Commodity Linked Credit

In order to achieve the stated objective, some specific objectives are required. These are to

- Determine the relationship between futures price at the CME and local New York prices. In order for the risk-contingency credit to work, there must be a reasonable high correlation between the futures price and the local prices. If the correlation is low, it will limit the effectiveness of the financial product in hedging business risks.

- Develop theoretical backgrounds for the effect of commodity-linked credit on farm businesses. By formally developing the relationship between business risks and financial risks, between hedging ratio and leverage ratio and between 
interest rate and collateral, the use of commodity-linked credit as an effective financial engineering tool to reduce risks and increase credit liquidity for dairy farmers is justified. These theories will also be used to design and calculate the key terms of commodity-linked loan/mortgage.

- To evaluate the efficacy of risk-contingent credit in terms of farm solvency and liquidity. The end point of this thesis is to implement commodity-linked credit to farmers. Thus, real case analysis is necessary to prove the legitimacy of such financial products.

In order to achieve the objective of this study, we will use a number of empirical approaches. For objective 1, we will gather information to get the historical relationship between Class III Milk nearby futures prices traded on CME and local milk price to find out the optimal hedge ratio; for objective 2, we will review literature of expected utility, we will design the product based on Black-Scholes option pricing model and commodity-linked credit pricing models as proposed by Turvey and Shee; for objective 3, a farm level Monte Carlo model will be built to assess the risks involved in dairy production and how commodity linked credit can balance these risks.

\subsection{Organization of the thesis}

In chapter 2, the general relationship between business risk, financial risks, debt structure and hedging ratio are discussed, we will also examine credited constrain and price risk problems faced by farmers. Theoretical framework of pricing commodity-linked credit is established. The data source and calculations of applying commodity contingent credit on a representative dairy farm model is provided in chapter 3 . In chapter 4 , the effects of the use of commodity-linked loan/mortgage on the cash flow and eventually on firm value under difference scenarios is examined. Chapter 5 concludes the thesis that commodity linked mortgage and operating loan are applicable financial instrument to hedge financial and business risks. 


\section{Chapter 2}

\section{THEORETICAL FRAMEWORK}

\subsection{Introduction}

This chapter will review the literature on financial risk, business risk, leverage ratio, hedging ratio and how commodity linked credit affect each of them. Also, other potential benefits of using commodity linked are explored through the point of view of development and production economics; finally, the formulas to price commodity linked loans and mortgages are derived.

\subsection{The mechanism of commodity linked credit}

Commodity linked credits are debt instruments with principal or coupon repayment contingent on one or more underlying commodities. They combine one's hedging strategy and financing decision under one covenant, which can mitigate illiquidity if inefficiency in any part of market exists.

The idea of commodity linked credits is not new, according to Turvey (2006), for example, during the U.S. Civil War, the confederate states issued war bonds with the payoff value linked to the price of cotton, which enable the bond coupon repayment to be maintained at a low level; In August of 1979, an agency of the Mexican Government issued bonds in local currency backed by oil. Each 1,000 pesos bond was linked to 1.95354 barrels of oil had a coupon rate of $12.65823 \%$ and duration of three years. At maturity they would be redeemed at face value plus the amount by which the market value of the reference oil bundle exceeded the face value plus all coupons received during the life of the bond, if this amount were positive; A more recent example involves Barclays Capital issuing bonds that pay regular coupons but repay the principal based on a basket of commodities. However, commoditylinked credits have not been widely used in farm businesses. 
The two types of commodity-linked credit products proposed in this paper are commodity-linked loan and commodity-linked mortgage, to meet the different credit terms required by farmers. These financial instruments work by charging a higher interest rate which is equal and opposite to the expected returns from an imbedded put option on class III milk futures price (A put option is a financial contract between two parties, the writer (seller) and the buyer of the option. The buyer acquires a short position by purchasing the right to sell the underlying instrument to the seller of the option for specified price (the strike price) during a specified period of time. If the option buyer exercises their right, the seller is obligated to buy the underlying instrument from them at the agreed upon strike price, regardless of the current market price. In exchange for having this option, the buyer pays the seller or option writer a fee (the option premium)). A commodity linked operating loan is a single period loan that repays principal and interest one period after borrowing. The lender, usually a financial institute uses the interest rate premium to buy a put option or basket of put options at origination. At the end of the period (month or year), if the commodity price falls below the strike price, the put option will expire in the money and the borrower will pay the loan less the intrinsic value of the option. If, on the other hand, the price is higher than the strike price, the put option will expire out of money and the borrower will pay the full loan amount. The nonlinear loan repayment graph for borrowers is shown in Figure 5.

Commodity linked mortgage works in the same way except that they will reduce mortgage repayment whenever price fall below the strike price, during the whole period when the mortgage is outstanding. Essentially, it is equivalent of the lender buying put options every year. If the risks faced by the borrowers, e.g. distributor, crop buyer to feed livestock are rising price risks, the lender could use the 
interest rate premium to buy a call option rather than a put option. The loan repayment will be reduced when the price of underlying commodity exceeds the strike price.

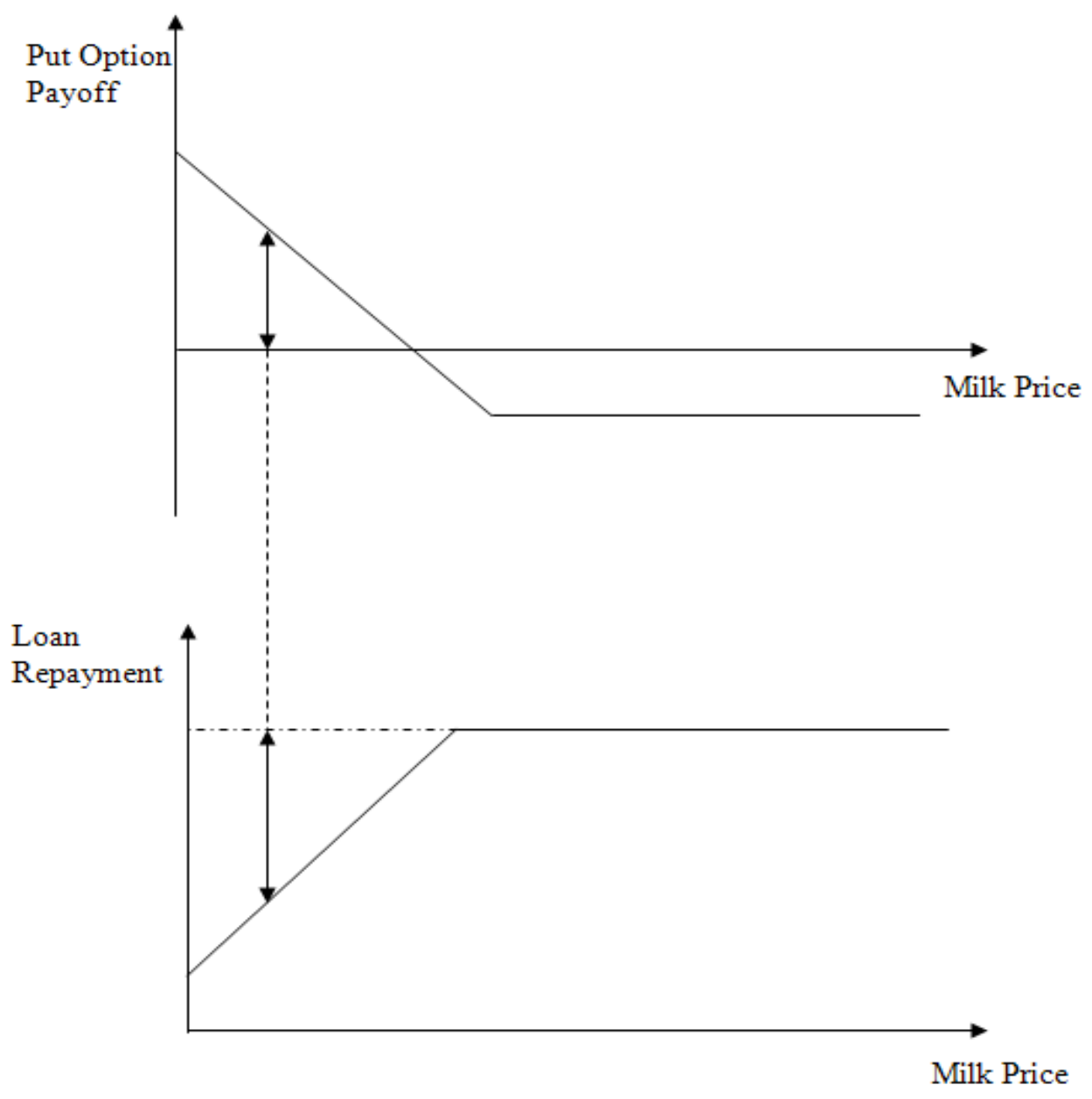

Figure 5 Principal Repayment of Commodity Linked Loan for Borrowers

\subsection{Financial risk, business risk, hedging ratio and leverage ratio}

One motivation for using commodity-linked credit is that commodity-linked credit improves farmers' welfare by releasing their credit constraint by reducing business risk and financial risk. This section aims to review theorems that illustrated how financial risk, business risk and debt structure influence each other as well as how commodity linked credit reduce the risks of farmers. In this setting, financial risk is defined as the incremental increase in variability of the return on equity (ROE) due to financial leverage. In other words, it is the uncertainty of net income and net cash 
flows attributed to the use of debt. Business risk of a company or project is the risk related to the uncertainty of revenues, i.e. milk prices.

First we prove that the total risk faced by a firm is the sum of its business risk and financial risk. From the Modigliani-Miller firm value (without tax) theorem,

$$
r_{e}=r_{A}+\frac{D}{E}\left(r_{A}-i\right)
$$

Rearranging terms in equation (1),

$$
\widetilde{r_{e}}=\widetilde{r_{A}}\left(\frac{A}{E}\right)-i\left(\sigma_{r_{A}}, \frac{D}{E}\right)\left(\frac{D}{E}\right)
$$

Where

$\widetilde{r_{e}}$ is return on equity, which is assumed to follow a stochastic process;

$\widetilde{r_{A}}$ is return on assets, which is assumed to follow a stochastic process;

A is total assets of the firm

$E$ is the equity of the firm

$\mathrm{D}$ is the amount of debt of the firm

Here $i\left(\sigma_{r_{A}}, \frac{D}{E}\right)$ represents that the cost of debt is increased as business risk and/ or leverage increase. We also exclude the impact of tax in the following analysis.

The expectation is

$$
\overline{r_{e}}=\overline{r_{A}}\left(\frac{A}{E}\right)-i\left(\frac{D}{E}\right)
$$

Variance,

$$
\sigma_{r_{e}}^{2}=\sigma_{r_{A}}^{2}\left(\frac{A}{E}\right)^{2}
$$

And standard deviation is

$$
\sigma_{r_{e}}=\sigma_{r_{A}}\left(1+\frac{D}{E}\right)
$$

When the firm is unleveraged (with $\mathrm{D}=0$ ), business risk, as fully reflected in the variance in ROA, is the same as variance of ROE; also, when the leverage ratio 
(representing the financial risk) moves, ROE will move in the same direction. In conclusion, the total risk is captured by the variance of ROE.

Since financial risk is influenced by debt structure, to further explore the relationship between financial risks and business risk, a utility function of return on equity and leverage structure is set up to examine how debt structure and business risk interact with each other. According to Collin, by assuming $\overline{r_{A}} \sim N\left(\overline{r_{A}}, \sigma_{r_{A}}^{2}\right)$, a negative exponential utility function of ROA can be expressed as

$$
E U=\overline{r_{A}} \frac{1}{1-\delta}-i \delta \frac{1}{1-\delta}-\frac{\rho}{2} \sigma_{r_{A}}^{2}\left(\frac{1}{1-\delta}\right)^{2}
$$

by assuming that $\delta^{2} \approx 0$, thus $1-\delta^{2} \approx 1$ and $\frac{1}{1-\delta} \approx 1+\delta$

Substitute these terms to Equation (6) we get

$$
E U=\overline{r_{A}}(1+\delta)-i(\delta) \delta-\frac{\rho}{2} \sigma_{r_{A}}^{2}(1+\delta)^{2}
$$

Equation (7) is the modified utility function derived by Turvey, The first-order condition for maximizing the expected utility of the rate of return on equity as a function of leverage choice is

$$
\frac{\partial E U}{\partial \delta}=\overline{r_{A}}-i(\delta)-\frac{\partial i(\delta)}{\partial \delta} \delta-\rho \sigma_{r_{A}}^{2}(1+\delta)=0
$$

The leverage structure that maximize utility is then

$$
\delta=\frac{\overline{r_{A}}-i(\delta)-\rho \sigma_{r_{A}}^{2}}{\rho \sigma_{r_{A}}^{2}+\frac{\partial i(\delta)}{\partial \delta}}
$$

What equation (9) says is that 1) the optimal leverage decreases as business risk increases, 2) higher leverage ratio tends to increase the interest rate, leading to a lower optimal leverage ratio. 3) The optimal debt ratio can be increased by either reduce risk aversion $\rho$ or reduce business risk $\sigma_{r_{A}}^{2}$, both of which can be satisfied by commodity-linked credit because the embedded option gives protection on downside risk and also decrease price volatility. 
To further prove the above statement on how optimal leverage ratio is affected by the imbedded option hedging strategy, a modified return on assets function developed by Turvey and Baker that include the return of hedging strategies is introduced as

$$
\widetilde{r_{A}}=\frac{Q \tilde{S}-c(Q)+\operatorname{Max}(0, K-S(T)) H-H \omega(K, S, T)}{A}
$$

Where Q is the output;

$c(Q)$ is production cost expressed as a function of output;

$\tilde{S}$ is the spot price of output commodity;

$\operatorname{Max}(0, K-S(T))$ is the payoff the imbedded put option;

$H$ is the hedging ratio;

$\omega(K, S, T)$ is the market price of the

The first term in equation (10) $Q \tilde{S}-c(Q)$ is the profit from normal production; the second term $\operatorname{Max}(0, K-S(T)) H$ refers to the cash flow obtained from the imbedded options. Thus, for a dairy farm with commodity-linked credit, the return on asset is composed of profit from production and the cost savings from commoditylinked credits.

The variance for equation (10) is then

$$
\sigma_{r_{A}}^{2}=\frac{\sigma_{s}^{2} Q^{2}+\sigma_{p}^{2} H^{2}+2 Q H \rho \sigma_{s} \sigma_{p}}{A^{2}}
$$

Where $\sigma_{s}^{2}$ is the spot price variance;

$\sigma_{p}^{2}$ is the variance of option payoffs;

$\rho$ is the correlation coefficient between option prices and spot prices;

Differentiating equation (11) with respect to hedging ratio $\mathrm{H}$ we get

$$
\frac{\partial \sigma_{r_{A}}^{2}}{\partial H}=\frac{2 H \sigma_{p}^{2}}{A^{2}}\left(1+\rho \frac{Q}{H} \frac{\sigma_{s}}{\sigma_{p}}\right)
$$

For a put option, the price of put option and underlying price move in the opposite direction, so $\rho$ must be less than zero, when the put option is in the money, 
$\rho=-1$. Also, the variance of underlying price should be larger than the variance of option prices, that is, $\frac{\sigma_{s}}{\sigma_{p}}>1$; also $\frac{\mathrm{Q}}{\mathrm{H}}>1$. Thus, when the put option is in the money,

$$
\frac{\partial \sigma_{r_{A}}^{2}}{\partial H}=\frac{2 H \sigma_{p}^{2}}{A^{2}}\left(1+\rho \frac{Q}{H} \frac{\sigma_{s}}{\sigma_{p}}\right)<0, S<K
$$

But when the option is at the money with zero payout, $\rho=0$ and $\sigma_{p}=0$ (no randomness in payout)

$$
\frac{\partial \sigma_{r_{A}}^{2}}{\partial H}=0, S>K
$$

Combining equation (13) and (14) illustrates the truncation effect of options, with price risk reduction below the strike, and no reduction above the strike.

Differentiate equation (6) with respect to $\delta$, the optimal leverage ratio is expressed as

$$
\delta^{*}=1-\frac{\lambda \sigma_{A}^{2}}{\left(R_{A}-i\right)}
$$

Differentiating equation (14) with respect to $\mathrm{H}$ yields

$$
\frac{\partial \delta^{*}}{\partial H}=-\frac{\lambda}{\left(R_{A}-i\right)} \frac{\partial \sigma_{A}^{2}}{\partial H}+\frac{\lambda \sigma_{A}^{2}}{\left(R_{A}-i\right)^{2}} \frac{\partial R_{A}}{\partial H}
$$

For a hedging strategy that increase the optimal leverage ratio, $\frac{\partial \delta^{*}}{\partial H}$ in equation (15) is greater than zero. This result is similar to Turvey and Baker (1991) except it is derived for option rather than futures. However, the result clearly shows the relationship between optimum debt and risk. In the presence of options the downside risk protection on those states of nature that adversely affect debt repayments are virtually eliminated. In the presence of these options, a farmer can optimally use more debt.

The embedded hedging strategies, in most cases put options, serves as a moderating term by reduce the downside risk of commodity price. This is because the price volatilities can be expressed as 


$$
\sigma_{s}^{2}=\int(s-\bar{s})^{2} f(s) d s
$$

With put option

$$
\sigma_{s_{K}}^{2}=\int_{0}^{K}(s-\bar{s})^{2} f(s \mid \Omega) d s+\int_{K}^{+\infty}(s-\bar{s})^{2} f(s \mid \Omega) d s
$$

The first term on the right hand side sum to zero because the put option truncated the payoff to a constant number when price falls below the strike price $\mathrm{K}$. rewriting (25) gives us

$$
\sigma_{s_{K}}^{2}=\int_{K}^{+\infty}(s-\bar{s})^{2} f(s \mid \Omega) d s<\sigma_{s}^{2}=\int(s-\bar{s})^{2} f(s) d s
$$

Since it is assumed that price risk is the sole source of business risk, we can say that a put option hedging strategy effectively reduces business risk, that is $\frac{\partial \sigma_{r_{A}}^{2}}{\partial \mathrm{H}}<0$. Increased financial risk is balanced by a reduction in the variance ROA.

\subsection{Credit constraints and the economics of production}

A recent study by Brian C. Briggerman and Charles Towe (2009), using US farm household data, shows that credit constrains in the US negatively affect the wellbeing of farm households by decreasing the input level and profit. Commodity linked credit could be used as a means to solve this problem. It is argued that for commodity linked credit, the higher interest rate serves as a substitute for collateral requirement that restrain farmers from access to credit. This is addressed this problem theoretically through the tool of production economy. According to Turvey and Shee The expected profit as a lender is expressed as

$$
E(\pi)=\left((1-\alpha) r x^{*}\right) i(1-\rho)+\left(C-(1-\alpha) r x^{*}(1+i)\right) \rho
$$

Where $\rho$ is the probability of default, $\mathrm{C}$ is the collateral and 1- $\alpha$ is the proportion of borrowed fund.

The first term on the right hand side of equation (20) represents the profit if loan is fully repaid; the second term represents when the farmer defaults on the loan, 
the lender will seize the collateral but lost the loan repayment of principal and interest $(1-\alpha) r x^{*}(1+i)$. Collateral can be seen as a risk sharing instrument that transfers the risk of lender to borrower.

In the face of default risk, lender could either set collateral $C=(1-\alpha) r x^{*}(1+i)$ if both lender and borrower are well aware of the risk, or the lender could set the collateral level at

$$
C=\frac{E^{*}-L x^{*}(i-\rho-2 i \rho)}{\rho}
$$

Where $E^{*}$ is a target return along the iso-revenue curve extracted from equation (20). Partial differentiating equation (21) by $E^{*}, \rho$ and $L$, respectively, where $L=$ $(1-\alpha) r x^{*}$ is the principal of the loan, we get

$$
\begin{gathered}
\frac{\partial C}{\partial E^{*}}=\frac{1}{\rho}>0 \\
\frac{\partial C}{\partial \rho}=\frac{(1-\alpha) r x^{*} i-E^{*}}{\rho} \geq 0 \\
\frac{\partial C}{\partial L}=\frac{-(i-\rho-2 i \rho) x^{*}}{\rho} \geq 0 \text { if } \frac{i}{1+2 i} \leq \rho
\end{gathered}
$$

What the above state is that 1) when business risk increases, the lender will increase collateral to mitigate the risk, 2) the collateral required by the lender is increased when the farmer requires more loans, 3) the profit of lender increases progressively as the collateral increases.

Another strategies employed by the lender is charging higher interest rate to mitigate insufficient collateral. The interest rate that could be charged without collateral can be obtained by setting $\mathrm{C}=0$ for equation (20)

$$
i^{*}=\frac{E^{*}+L \rho}{L(1-2 \rho)}
$$

Differentiating equation (25) with respect to $\mathrm{L}$ is

$$
\frac{\partial i^{*}}{\partial L}=-\frac{E^{*}}{L^{2}(1-2 \rho)}
$$


The lower boundary for $i^{*}$ is when default risk is zero, then $i_{\rho=0}^{*}=\frac{E^{*}}{(1-\alpha) r x^{*}}<i^{*}$; combining equation (24) and (26), the marginal rate of substitute between collateral and interest rate for a given loan size is

$$
\frac{\Delta C}{\Delta i^{*}}=\frac{\frac{\partial C}{\partial L}}{\frac{\partial i^{*}}{\partial L}}=\frac{(i-\rho-2 i \rho)\left((1-\alpha) r x^{*}\right)^{2}(1-2 \rho)}{\rho E^{*}} \leq 0
$$

For

$$
\frac{i}{1+2 i} \leq \rho \leq \frac{1}{2}
$$

Equation (27) demonstrates that there is a substitute effect between collateral and interest rate, when the default risk and the interest rate charged are in a reasonable range.

The amount of interest rate premium to compensate for less collateral is calculated below. It is assumed that a lender is willing to give up collateral for more interest income and a non-asset based contingency payment. In other words, the lender is indifferent between a loan repaid in full or a partial repayment contingent on price risk. Also, to preserve collateral, borrower may be willing to pay a premium on interest rate to substitute collateral requirement. This is described as

$$
\frac{(1-\alpha) r x^{*}(1+i)}{1+r_{f}}=\frac{(1-\alpha) r x^{*}\left(1+i^{*}\right)}{1+r_{f}}-\varphi p
$$

Where $p$ is the price of insurance with value depending on the current price of commodity, mostly in the form of put option;

$r_{f}$ is the appropriate risk free discount factor; $\varphi=\frac{(1-\alpha) r x^{*}\left(1+i^{*}\right)}{K}$ is the hedging ratio

If the contingency is required to cover both principal and interest repayment, the effective interest rate faced by the borrower is then 


$$
i^{*}=\frac{(1+i)}{1-\frac{p}{K}\left(1+r_{f}\right)}-1
$$

From farmers' perspective, their profit of production is

$$
\pi=S Q(x \mid \rho)-(\alpha r+(1-\alpha) r(1+i)) x
$$

If we assume a quadratic production function $Q(x \mid \rho)=a+b x+c x^{2}$ where $\mathrm{a}, \mathrm{b}>0, c<0$, then the input that maximize profit is

$$
\begin{aligned}
& \frac{\partial \pi}{\partial x}=S(b+2 c x)-(\alpha r+(1-\alpha) r(1+i))=0 \\
& x^{*}=\frac{(\alpha r+(1-\alpha) r(1+i))}{2 c S}-\frac{b}{2 c} \\
& \frac{\partial x^{*}}{\partial \alpha}=-\frac{r i}{2 c S}>0 \\
& \frac{\partial x^{*}}{\partial S}=-\frac{(\alpha r+(1-\alpha) r(1+i))}{2 c S^{2}}>0 \\
& \frac{\partial x^{*}}{\partial i}=\frac{(1-\alpha) r}{2 c S}<0 \\
& \frac{\partial^{2} x^{*}}{\partial S \partial i}=-\frac{(1-\alpha) r}{2 c S^{2}}>0
\end{aligned}
$$

From above derivations we can conclude that 1) the higher commodity price and initial wealth of the farm increase input investment, as shown in equation (34) and $(35)$;2) higher loan interest rate decrease input demand, which can be offset by higher commodity price, as shown in equation (36) and (37).

To see the impact of risk-contingent credit on firm production, we first substitute the interest rate in the optimal input function without commodity-linked loan by the effective interest with risk-contingent credit derived from equation (30), then equation (33) is changed to

$$
x^{*}=\frac{(\alpha r+(1-\alpha) r(1+i))}{2 c S\left(1-\frac{p}{K}\left(1+r_{f}\right)\right)}-\frac{b}{2 c}
$$




$$
\frac{\partial x^{*}}{\partial K}=\frac{\left(K \frac{\partial p(K)}{\partial K}-p\right)\left(1+r_{f}\right)}{2 c S\left(K-p\left(1+r_{f}\right)\right)^{2}}<0
$$

The commodity-linked loan will decrease optimal input level by increase coverage on the underlying commodity. However, this decreasing effect will be offset by increasing expected marginal revenue product. For example, if we assume there are two possible price outcomes $S_{1}, S_{2}$, with $S_{1}$ representing a high price and $S_{2}$ representing a low price. Then the expected profit will be $\pi=S_{1} Q(x \mid \rho)(1-\rho(K))+S_{2} Q(x \mid \rho) \rho(K)-(\alpha r+(1-\alpha) r(1+i(K))) x$

Differentiating equation (42) we get

$$
\frac{\partial Q(x \mid \rho)}{\partial x}\left(\left(S_{2}-S_{1}\right) \rho(Z)+P_{1}\right)-(\alpha r+(1-\alpha) r(1+i(Z)))=0
$$

Partial differentiation of equation (42) with respect to strike price Z,

$$
\frac{\partial Q(x \mid \rho)}{\partial x}\left(\left(S_{2}-S_{1}\right) \frac{\partial \rho(Z)}{\partial K}\right) d Z=(1-\alpha) r \frac{\partial i(K)}{\partial K} d K
$$

Since increased coverage reduce the possibility of low price outcome, the term

$\frac{\partial \rho(K)}{\partial K}<0$, then the left hand side term is positive, which can be interpret as marginal revenue product increases with increased coverage. The right hand side of equation (46) is the marginal cost, which increases as increased insurance coverage.

Graphically, the MRP function will be shifted rightward and the MC function will be shifted upward by increased insurance coverage. The farmer will expand their input level as long as the increase in MRP exceeds the increase in MC.

\subsection{Pricing of Commodity Linked Loan}

The mechanism of how commodity-linked loan works has already been stated in previous chapters. In the case of a dairy farm, farmers borrow from bank certain amount in time 0 to lease/buy cattle or buy feeds and one period later, they will pay back the loan through cash flow they get from selling milk at year end. The amount to 
be repaid will depend on the selling price of milk. Thus, at year one, the cash flow of such a loan, with principal $f$ and embedded put option $p$ can be expressed as

$$
V_{T}=f e^{r^{\prime} T}-\varphi \operatorname{Max}(0, K-S(T))
$$

Where $r^{\prime}$ is the interest rate charged by the lender and $\varphi=\frac{f}{K}$ is a scale parameter. The present value of this cash flow is

$$
V_{0}=f e^{r^{\prime} T} e^{-r_{f} T}-\frac{f}{K} E\left(\operatorname{Max}(0, K-S(T)) e^{-r_{f} T}\right.
$$

$E\left(\operatorname{Max}(0, K-S(T)) e^{-r_{f} T}\right.$ in equation (48) represents the value of the put option at year zero, $r_{f}$ is the discount rate. Thus, $E\left(\operatorname{Max}(0, K-S(T)) e^{-r_{f} T}=p(S, t)\right.$ for equation (48)

The present value of a plain vanilla loan without the embedded put option is

$$
V_{0}{ }^{\prime}=f e^{r T} e^{-r_{f} T}
$$

As argued by Hans Bingswanger and Donald Sillers, for a risk-averse borrower, the preservation of capital results in higher utility than the expected utilities of collateral loss in the face of default and reduction in interest costs, thus, borrower prefer a loan with higher interest which allow him to default (involuntarily) at no additional cost $<r^{\prime}$. To make lender indifferent between loan with embedded option and without embedded option,

$$
V_{0}^{\prime}=V_{0}
$$

Substitute equation (44) and (45) to (46), the interest rate $r^{\prime}$ then can be derived as

$$
\begin{gathered}
f e^{r^{\prime} T} e^{-r_{f} T}-\frac{f}{K} E\left(\operatorname{Max}(0, K-S(T)) e^{-r_{f} T}=f e^{r^{\prime} T} e^{-r_{f} T}-\varphi p=f e^{r T} e^{-r_{f} T}\right. \\
r^{\prime}=\frac{\ln \left(\frac{\varphi p}{f} e^{r_{f} T}+e^{r T}\right)}{T}
\end{gathered}
$$

The put option $p$ in equation (47) at initiation will be priced using Black-Scholes Option Pricing Model described below. 
The Black-Scholes model is used in this paper to price put and call options, under the assumption that the underlying asset price follows a geometric brownian motion and evolves from risk-neutral measure. The value of call option on commodity price, in terms of the Black-Scholes parameters is:

$$
\begin{gathered}
c(S, t)=S N\left(d_{1}\right)-K e^{-r(T-t)} N\left(d_{2}\right) \\
d_{1}=\frac{\ln \left(\frac{S}{k}\right)+\left(r+\frac{\sigma^{2}}{2}\right)(T-t)}{\sigma \sqrt{T-t}} \\
d_{2}=d_{1}-\sigma \sqrt{T-t}
\end{gathered}
$$

The price of a put option is

$$
p(S, t)=K e^{-r_{f}(T-t)} N\left(-d_{2}\right)-S N\left(-d_{1}\right)
$$

Where

$\mathrm{N}($.$) is the cumulative distribution function of the standard normal distribution.$

$\mathrm{t}$ is the current time;

$\mathrm{T}$ is the duration of the option;

$\mathrm{S}$ is the spot price;

$\mathrm{K}$ is the strike price;

$\mathrm{r}$ is the annualized risk free rate;

$\sigma$ is annualized volatility in the log-return of the underlying.

Then pricing option on futures is derived from equation (51) as shown below. Futures price for the underlying commodity price is

$$
F_{t}=S_{t} e^{r(T-t)}
$$

Substituting (52) into equation (51) gives Black's option price on futures formula

$$
p(F, t)=K e^{-r_{f}(T-t)} N\left(-d_{2}\right)-F e^{-r_{f}(T-t)} N\left(-d_{1}\right)
$$


For purpose of ease, we assume that the U.S. option market is efficient. The option prices listed fully reflect the true value of that option and there is no arbitrage opportunity.

\subsection{Pricing Commodity Linked Mortgage}

For dairy farmers who need mortgage to financing longer term projects or operation will use commodity-linked mortgage instead. During the T periods that the mortgage is outstanding, the mortgage repayment will be reduced whenever dairy price fall below the strike price of put option at repayment time. The lender essentially buys put option every period.

For a $\mathrm{T}$ period mortgage with loan mount of $f$, the annuity formula is given by

$$
A(i)=f\left(\frac{1-(1+i)^{-T}}{i}\right)^{-1}
$$

For a commodity-linked mortgage, since the option expires one period after initiation and annuity repayment starts from period 1, the lender should start buying put option for protection from period 0 . The cash flow of commodity-linked mortgage for the lender includes: a cash outflow amount equal to the price of options every year from period 0 to period $\mathrm{T}-1$, cash inflow of the annuity repayment $\mathrm{A}$ from period 1 to period $\mathrm{T}$, as shown in the cash flow diagram.

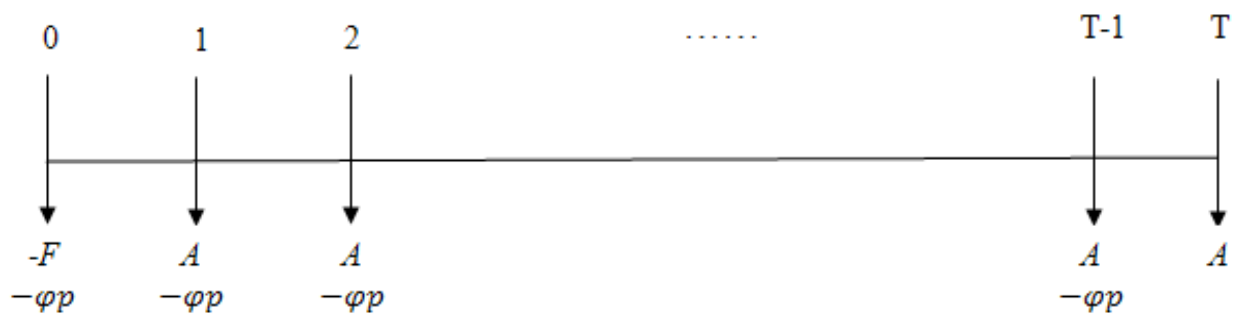

Figure 6 Cash Flow of Commodity Linked Mortgage For Lenders

The present value is then 


$$
P V=\frac{A\left(r_{m}^{\prime}\right)}{r_{f}}\left(1-e^{-r_{f} T}\right)-A\left(r_{m}\right) \frac{p}{K_{i}} \frac{\left(1-e^{-r_{f} T}\right)}{r_{f}} e^{r_{f}}
$$

Where the hedging ratio $\varphi=\frac{A\left(r_{m}\right)}{K_{i}}$

for a plain vanilla mortgage, the present value of all annuity repayments are

$$
V^{\prime}=\frac{A\left(r_{m}\right)_{1}}{\left(1+r_{f}\right)}+\frac{A\left(r_{m}\right)_{2}}{\left(1+r_{f}\right)^{2}}+\cdots+\frac{A\left(r_{m}\right)_{t}}{\left(1+r_{f}\right)^{t}}
$$

with $A\left(r_{m}\right)_{1}=A\left(r_{m}\right)_{2}=\cdots=A\left(r_{m}\right)_{t}=A\left(r_{m}\right)$

By solving equation (56) we get the annuity amount

$$
P V_{0}=A\left(r_{m}\right) \frac{\left(1-e^{-r_{f} T}\right)}{r_{f}}
$$

If the lender is indifferent between a plain vanilla mortgage and a commoditylinked mortgage, then $P V_{0}$ of equation (57) must equal $P V$ of equation (55), that is

$$
\frac{A\left(r_{m}^{\prime}\right)}{r_{f}}\left(1-e^{-r_{f} T}\right)-A\left(r_{m}\right) \frac{p}{K_{i}} \frac{\left(1-e^{-r_{f} T}\right)}{r_{f}} e^{r_{f}}=A\left(r_{m}\right) \frac{\left(1-e^{-r_{f} T}\right)}{r_{f}}
$$

Reorganizing equation (58) we get

$$
A\left(r_{m}^{\prime}\right)=A\left(r_{m}\right)\left(1+\frac{p}{K_{i}} e^{r_{f}}\right)
$$

Substitute equation (54) to equation (59), we can calculate the interest rate for a commodity-linked mortgage as

$$
\frac{1-\left(1+r_{m}^{\prime}\right)^{-T}}{r_{m}^{\prime}}=\left(\frac{1-\left(1+r_{m}\right)^{-T}}{r_{m}}\right)\left(1+\frac{p}{K_{i}} e^{r_{f}}\right)^{-1}
$$

Note that the above formula is tenable if we assume that the pattern of random walk is the same during the T periods, that is the drift, volatility of price is the same every year, and each year the option strike price is a fixed proportion of spot price, then after scaling, the put option price is the same each year. Mathematical prove is provided below.

Let $S_{i}, i \in T$ represents the beginning of period commodity price of year i. We assume that $r_{0}=r_{1}=\cdots=r_{T}$ and $\sigma_{1}=\sigma_{2}=\cdots=\sigma_{T}$, also, $K_{i}=z F_{i}$ for $i \in T$. Where $r_{i}$ is the risk free rate, $\sigma_{i}$ is the volatility of the underlying futures contract, $z$ is 
a constant representing a fix proportion of spot futures price, the Black-Scholes Model from Equation (51) to Equation (54) is modified to

$$
\begin{array}{r}
d_{1 i}=\frac{\ln (Z)+\left(r_{i}+\frac{\sigma_{i}^{2}}{2}\right)(T-t)}{\sigma_{i} \sqrt{T-t}} \\
d_{2 i}=d_{1 i}-\sigma_{i} \sqrt{T-t} \\
p_{i}(S, t)=K_{i} e^{-r_{i}(T-t)}\left(N\left(-d_{2}\right)-N\left(-d_{1}\right) / z\right)
\end{array}
$$

The prices after scaling with $\varphi_{i}=\frac{A}{K_{i}}$

$$
A \frac{p_{i}(S, t)}{K_{i}}=A e^{-r_{i}(T-t)}\left(N\left(-d_{2}\right)-N\left(-d_{1}\right) / z\right)
$$

for $\in T$. Where A is the annuity amount, Equation (62) is a function of constants and known parameters for each period. 
Chapter 3

DATA DESCRIPTION AND METHODS

\subsection{Introduction}

This chapter provides detailed description of the procedures of building the reference farm financial statement model, the modification made to the model and the sources of data in building this model.

\subsection{Model establishment and modification}

The farm model in this paper is 'Dairy Proforma Calculator' spreadsheet downloaded from the website of Center for Dairy Profitability, University of Wisconsin-Madison, http://cdp.wisc.edu/Decision\%20Making\%20Tools.htm. To better represent the realistic situation faced by a typical dairy farm in New York State, the following modifications are made to this model.

1) generating randomness to monthly milk price received by NY dairy farmers

The main function of the designed commodity-linked credit is to hedge the risk of milk price fluctuation for dairy farmers with imbedded options on milk futures, thus, to illustrate the effect of such financial product to a dairy farm, adding randomness to milk price received will imitate the volatilities in milk price.

Because the imbedded option is written on class III milk futures, but the risks that is aimed to be hedged is on local milk spot price, it is important to show that class III milk futures price and spot price are highly correlated so that the hedging is effective. After showing the high correlation between futures price and local spot price, milk futures price is generated using geometric brownie motion. Then a regression with New York State all milk price received on futures price is run to obtain the coefficient and error terms. Based on the regression formula and the generated milk futures price, monthly New York State all milk prices are computed and added to the 
reference farm model. Details on how data are collected and calculated are described below.

For the imbedded hedging to be effective, it is essential to examine whether the class III milk futures price is a good approximation of class III milk spot price. In noarbitrage theory, the relationship between futures price and spot price is $F(t)=$ $S(t) \times e^{r(T-t)}$, when futures contract is close to settlement date (nearby), the time value $e^{r(T-t)}$ portion become insignificant and $F(t) \approx S(t)$.

The announced class III daily futures price by contract month is collected from http://future.aae.wisc.edu/data/futures/by_contract/3, a 'Understanding Dairy Markets' website maintained by Professor Brain W. Gould of Department of Agriculture and Applied Economics in University of Wisconsin.

As defined by CME, nearby class III milk futures trading terminates immediately preceding the day on which the USDA announces the Class III price for that contract month (usually at the end of that specific month or the start of next month).Thus, nearby contract from January 2000 to March 2010 are extract to represent the class III milk spot price for each contract month. For example, NASS announced March 2005 milk price on April $4^{\text {th }}, 2005$ and the March 05 contract stopped trading on April $1^{\text {st; }}$; then daily March 05 futures price from 03/01/2005 to 04/01/2005 are used to represent spot prices for that period.

Class III milk spot prices are derived from a milk formula developed by ED Jesse and Bob Cropp. According to Ed Jesse and Bob Cropp, The class III milk is composed of the combined value per hundredweight of butterfat in butter and in cheese, protein in cheese and other (nonfat/non-protein) milk solids in whey. The class III milk spot price is calculated using formula derived by ED Jesse and Bob Cropp as 
Class III price

$$
\begin{aligned}
& =9.64 \times \text { NASS Cheese Price }+0.42 \times \text { NASS Butter Price } \\
& +5.86 \times \text { NASS Dry Whey Price }-2.57
\end{aligned}
$$

where the NASS Cheese Price is a weighted average of the 40-pound blocks and 500pound barrels of cheddar cheese with weights based on sales volume; also the 500pound barrel price used is adjusted to represent $38 \%$ moisture content. Raw data of NASS cheddar cheese - 40-pound blocks prices/sales volume, NASS cheddar cheese 500 pound-barrels prices/sales volume, dry whey prices and butter prices are obtained from National Agricultural Statistics Service on weekly bases.

To generate the milk price received by New York State dairy farmers, CME Class III milk futures prices should also be compared with New York State class III milk prices, however, the closest data available for New York State is monthly all milk prices from NASS. Thus, we average weekly calculated class III milk spot prices and daily futures price to monthly prices and compare them with monthly NY all milk price. The preliminary results are shown in Figure 7.

Graphically it can be seen that the line representing Class III milk futures price almost overlap with the line representing calculated Class III milk spot price, the correlation between calculated spot price and futures price is 0.979 ; New York state Milk prices are generally higher than futures price, but the general trend in price movements are synchronized.

To quantitatively shown the relationship between futures price and New York state all milk price, we run a simple regression of New York State all milk price on Class III Milk Futures price. The results are displayed in Table 3. 


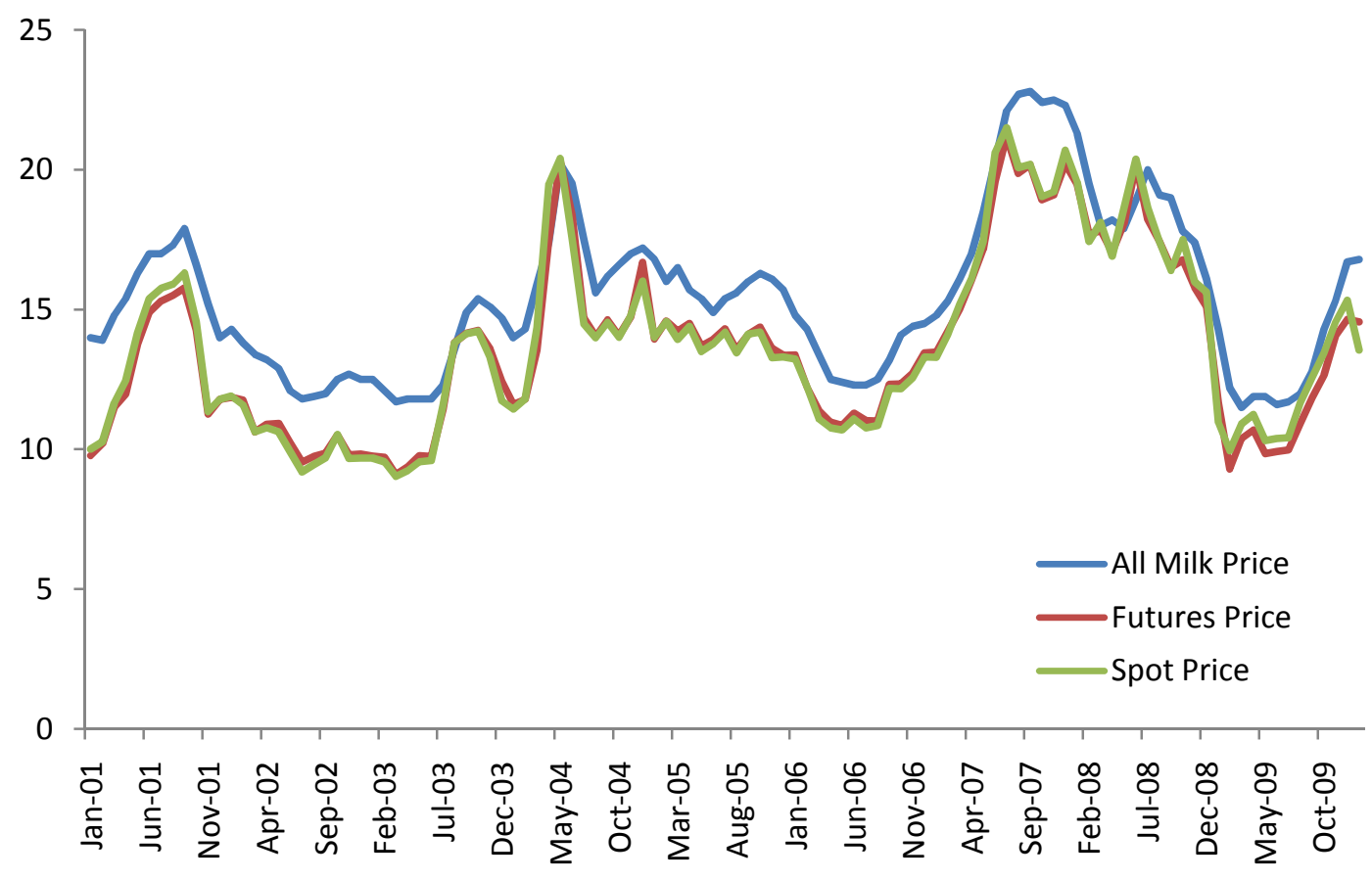

Figure 7 Monthly Class III Milk Futures and Spot Price, NY All Milk Price Comparison From 2001 to 2010 
Table 3 Regression Result of NY All Milk Price on Futures Price

\begin{tabular}{|c|c|c|c|c|c|c|c|c|}
\hline \multicolumn{2}{|c|}{ Regression Statistics } & & & & & & & \\
\hline Multiple R & 0.957398 & & & & & & & \\
\hline R Square & 0.916611 & & & & & & & \\
\hline Adjusted R Square & 0.915832 & & & & & & & \\
\hline Standard Error & 0.84028 & & & & & & & \\
\hline Observations & 109 & & & & & & & \\
\hline \multicolumn{9}{|l|}{ ANOVA } \\
\hline & $D f$ & $S S$ & $M S$ & $F$ & $\begin{array}{c}\text { Significance } \\
F\end{array}$ & & & \\
\hline Regression & 1 & 830.438 & 830.438 & 1176.141 & $1.53 \mathrm{E}-59$ & & & \\
\hline Residual & 107 & 75.54953 & 0.70607 & & & & & \\
\hline \multirow[t]{2}{*}{ Total } & 108 & 905.9875 & & & & & & \\
\hline & Coefficients & $\begin{array}{l}\text { Standard } \\
\text { Error }\end{array}$ & $t$ Stat & $P$-value & Lower 95\% & $\begin{array}{c}\text { Upper } \\
95 \%\end{array}$ & $\begin{array}{l}\text { Lower } \\
95.0 \% \\
\end{array}$ & $\begin{array}{l}\text { Upper } \\
95.0 \% \\
\end{array}$ \\
\hline Intercept & 3.258236 & 0.364925 & 8.928503 & $1.35 \mathrm{E}-14$ & 2.534815 & 3.981658 & 2.534815 & 3.981658 \\
\hline $\mathrm{X}$ Variable 1 & 0.894758 & 0.02609 & 34.29491 & $1.53 \mathrm{E}-59$ & 0.843038 & 0.946479 & 0.843038 & 0.946479 \\
\hline
\end{tabular}


Thus, the formula for calculating New York State milk price is $\mathrm{P}_{\mathrm{t}}=3.258236+$ $0.894758 \times F_{t}+\varepsilon(0,0.70607)$

Where $\mathrm{P}_{\mathrm{t}}$ is the New York State all milk price, $\mathrm{F}_{\mathrm{t}}$ is the generated futures price, $\varepsilon(0,0.70607)$ is the error term, which is normally distributed with mean of zero and standard deviation of 0.70607

2) derivation of futures price by geometric Brownian motion Class III milk futures price is generated by assuming the underlying commodity spot price follows geometric Brownian motion, which is the basic assumptions in Black-Scholes option pricing model, that is, it satisfies equation (64)

$$
\frac{d S_{t}}{S_{t}}=(\mu-\lambda \sigma) d t+\sigma d W_{t}
$$

Where $\frac{d S_{t}}{S_{t}}$ is the percentage change in price during time dt; $W_{t}$ is a Wiener process or Brownian motion; both $\mu$, the drift and $\sigma$, the variance of percentage return are constants. $\mu-\lambda \sigma$ represents the risk neutral returns. Using Ito's Lemma,

$$
d\left(\ln S_{t}\right)=\left(\mu-\lambda \sigma-\frac{\sigma^{2}}{2}\right) d t+\sigma d W_{t}
$$

Thus,

$$
S_{t}=S_{0} \exp \left(\left(\mu-\lambda \sigma-\frac{\sigma^{2}}{2}\right) t+\sigma W_{t}\right)
$$

The random variable $\ln \left(\frac{S_{t}}{S_{0}}\right)$ is normally distributed with mean $\left(\mu-\frac{\sigma^{2}}{2}\right) t$ and variance $\sigma t$.under the risk neutral assumption,

For asset $f_{1}$ and $f_{2}$ with geometric Brownian motion

$$
\begin{aligned}
& d f_{1}=\mu_{1} f_{1} d t+\sigma_{1} f_{1} d W \\
& d f_{2}=\mu_{2} f_{2} d t+\sigma_{2} f_{2} d W
\end{aligned}
$$

The only source of risk for these two assets is $d W$, the wiener process. By creating a portfolio

$$
P=\sigma_{2} f_{2} f_{1}-\sigma_{1} f_{1} f_{2}
$$

$d W$ is eliminated and $\mathrm{P}$ is riskless, which should earn the risk free return 


$$
d P=r P d t
$$

Differentiating equation (66) we can get

$$
d P=\sigma_{2} f_{2} d f_{1}-\sigma_{1} f_{1} d f_{2}
$$

Substitute (66), (67) into (70)

$$
d P=\left(\mu_{1} \sigma_{2} f_{2} f_{1}-\mu_{2} \sigma_{1} f_{1} f_{2}\right) d t
$$

By solving (70) and (71), we get

$$
\frac{\mu_{1}-r}{\sigma_{1}}=\frac{\mu_{2}-r}{\sigma_{2}}=\lambda
$$

$\boldsymbol{\lambda}$ is the market risk premium.

Substitute (72) into (65) we get the formula that will be used to generate the spot price

$$
\begin{gathered}
S_{t}=S_{0} e^{\left(\left(r-\frac{\sigma^{2}}{2}\right) t+\sigma N(0,1) / \sqrt{t}\right)} \\
\sigma^{2}=\operatorname{var}\left[\ln \left(\frac{S_{t}}{S_{t-1}}\right)\right] \sqrt{12}
\end{gathered}
$$

Where $\sigma$ is the annualized standard deviation of log return of commodity price, $S_{t}$ is commodity price at time t, $N(0,1)$ is standardized normal distribution. to proceed to futures price brownie motion function, substitute equation (55) to (73),

$$
F_{t} e^{-r(T-t)}=F_{0} e^{-r t} e^{\left(\left(r-\frac{\sigma^{2}}{2}\right) t+\sigma N(0,1) / \sqrt{t}\right)}
$$

Rearranging terms

$$
F_{t}=F_{0} e^{\left(\left(-\frac{\sigma^{2}}{2}\right) t+\sigma N(0,1) / \sqrt{t}\right)}
$$

Where

$$
\sigma^{2}=\operatorname{var}\left[\ln \left(\frac{F_{t}}{F_{t-1}}\right)\right] \sqrt{12}
$$

Which is calculated from historical nearby futures price data obtained and described in 3) Correlate feed cost price with milk price

Feed cost price volatility is another major source of risk for dairy farmers.

Feed cost and milk price, the risk source for expense and revenue together determines the profit margin of dairy farms. When milk price and feed cost do not move together, 
the profit margin will fluctuate accordingly. Thus, feed cost price risk has to be considered to complete the model.

The feed cost considered in this paper is corn, which is the main grain used to feed cows and soybean, which provide protein to cows. First by the same method described for generating corn futures, corn prices and soybean prices are generated from geometric brownie motion. The volatilities in the geometric brownie motion of corn and soybean are calculated from implied volatilities of at the money options, using options calculator from CBOE. A snapshot of the implied volatilities calculator and all inputs are shown in appendix II. Then from CME, one complete contract of soybean, corn and class III milk futures prices each, in the same contract month (for this paper, it is March contract) are obtained and the correlation coefficient among these three products are calculated as

Table 4 Correlation Coefficient Matrix for Soybean, Class III Milk and Corn Price

\begin{tabular}{lrrr}
\hline & Soybean & Class III Milk & Corn Price \\
\hline Soybean & 1 & & \\
Class III Milk & 0.10331 & 1 & \\
Corn Price & 0.736894 & 0.099168193 & 1 \\
\hline
\end{tabular}

then using the correlate time series function in @ risk, corn, soybean and milk prices are correlated, with the correlation coefficient calculated shown in Table 4.

4) Introduce volatilities to monthly milk production

Since milk production volume varies across months during a year, cyclic in milk production is introduced to the model. Pert distribution in @ risk is assumed for the weight of milk production volume each month during a year. The inputs for pert distribution, minimum, maximum and most likely weights are derived using the following steps. First historical data of NY state milk production per month from 1970 to 2009 is obtained from NASS database. Then the weights of milk production volume each month in milk production of a year, during 1970 to 2009 are computed. For each 
month except December, the minimum, maximum and most likely (average) weights are obtained. Since the weight of each month in a year should sum to 1 , the December weight each year is simply 1 subtracted by the sum of the weights of the previous eleven months in that year, as shown in Table 5. These data are used as inputs for pert distribution.

5) Creating line of credit

Cyclicity in milk production, fluctuation in milk price and feed cost cause cyclicity in free cash dairy farmers could generate each month. A line of credit is set up by bank to record the balance of operating loan on account during each month in a year. All free cash flow, after paying down scheduled intermediate and long term debt, goes through the line of credit before adding to the cash account. If operating cash flow in that month is insufficient to cover intermediate and long term debt repayment, the line of credit is increased. As illustrated in Table 6, at the beginning of year, farm has an operating loan of $\$ 6,000$ and $\$ 1,200$ cash on balance sheet. In the $1^{\text {st }}$ month, farm generates $\$ 836$ free cash, together with the cash on balance sheet, will pay down the operating loan. The ending line of credit is then $\$(6,000-1,200-836)=\$ 3,964$. In the $2^{\text {nd }}$ month, the farmer is short of $\$ 246$ cash, so the line of credit is debit of $\$ 246$ and increased from previous balance of $\$ 3,964$ to $\$(3964+246)=\$ 4,210$. In the same way, the line of credit balance is constantly adjusting to the free cash flow account. The interest for operating loan is paid at the end of each month based on the beginning of month loan balance. The end of year cumulative cash and line of credit balance, in Table $6 \$ 0$ and $\$ 7,564$ respectively are shown as cash and operating loan on the end of year balance sheet.

6) Implementing commodity linked operating loan In a second model, the commodity linked operating loan is bought and priced every month. 
Table 5 Monthly Milk Production

\begin{tabular}{|l|c|c|c|c|c|c|c|c|c|c|c|c|}
\hline & Jan & Feb & Mar & Apr & May & Jun & Jul & Aug & Sep & Oct & Nov & Dec \\
\hline average & 0.0831 & 0.0772 & 0.0869 & 0.0863 & 0.0910 & 0.0875 & 0.0847 & 0.0826 & 0.0795 & 0.0810 & 0.0778 & 0.0824 \\
\hline $\max$ & 0.0865 & 0.0817 & 0.0903 & 0.0915 & 0.0980 & 0.0944 & 0.0865 & 0.0859 & 0.0816 & 0.0844 & 0.0815 & 0.0863 \\
\hline $\min$ & 0.0796 & 0.0740 & 0.0843 & 0.0827 & 0.0875 & 0.0838 & 0.0820 & 0.0775 & 0.0743 & 0.0771 & 0.0727 & 0.0781 \\
\hline
\end{tabular}

Table 6 Line of Credit

\begin{tabular}{|l|r|r|r|r|r|r|r|r|r|r|r|r|r|}
\hline & begin & 1 & 2 & 3 & 4 & 5 & 6 & 7 & 8 & 9 & 10 & 11 & 12 \\
\hline Free cash & & 836 & $(246)$ & 1,305 & $(3,237)$ & $(3,300)$ & $(1,680)$ & 2,635 & 2,282 & 1,763 & $(2,849)$ & $(460)$ & 185 \\
\hline Line of credit & 6,000 & 3,964 & 4,210 & 2,905 & 6,142 & 9,442 & 11,122 & 8,487 & 6,205 & 4,441 & 7,290 & 7,750 & 7,564 \\
\hline Final Cash & 1,200 & 0 & 0 & 0 & 0 & 0 & 0 & 0 & 0 & 0 & 0 & 0 & 0 \\
\hline $\begin{array}{l}\text { Cumulative } \\
\text { cash }\end{array}$ & & 0 & 0 & 0 & 0 & 0 & 0 & 0 & 0 & 0 & 0 & 0 & 0 \\
\hline
\end{tabular}


To calculate the interest rate, the at the money option is priced every month, using the same time to maturity and volatilities. Because the strike price is a fixed proportion of spot price, the interest rate is fixed, as proved in section 2.6. The calculated annual interest rate for commodity linked operating loan is $45.23 \%$, as illustrated in Table 7.

The beginning loan balance in Table 8 is the line of credit account. As described above, surplus or deficit of operating cash will always go through line of credit account first. The hedge ratio will equal to beginning balance of line of credit divided by strike price and the option payout for commodity linked operating loan will stay in the line of credit account. For example, the beginning balance of line of credit for the $1^{\text {st }}$ month is $\$ 6,000$. Interest payment for the $1^{\text {st }}$ month is then $\$ 6,000 \times$ $45.12 \% / 12=226.12$. At the end of the $1^{\text {st }}$ month, class III milk price dropped to $\$ 13.73$ (equals the spot price at beginning of the $2^{\text {nd }}$ month), the hedge ratio is $6,000 / 13.78=435.41$, the option payout is then $435.41 \times \max (13.78-13.73,0) \approx \$ 21.02$. This amount, together with operating cash flow generated in the first month, will pay down line of credit to $\$ 5339.6$. $\$ 5339.6$ will serve as the beginning balance for the $2^{\text {nd }}$ month to calculate the hedge ratio and interest expense for that month.

7) Implementing commodity-linked mortgage

Assume the base farm originally has a 3.75\% 20 year mortgage with monthly repayment. In a third model with commodity linked mortgage, twelve at the money options are purchased by bankers at the beginning of each year set to expire individually over the next 12 months. The average of these twelve option price is used to calculate the interest rate of commodity-linked mortgage. 
Table 7 Pricing of Option for Commodity Linked Loan

\begin{tabular}{|c|c|c|c|c|c|c|c|c|c|c|c|c|}
\hline & 1 & 2 & 3 & 4 & 5 & 6 & 7 & 8 & 9 & 10 & 11 & 12 \\
\hline $\mathrm{T}$ & $1 / 12$ & $1 / 12$ & $1 / 12$ & $1 / 12$ & $1 / 12$ & $1 / 12$ & $1 / 12$ & $1 / 12$ & $1 / 12$ & $1 / 12$ & $1 / 12$ & $1 / 12$ \\
\hline$\sigma$ & $29.02 \%$ & $29.02 \%$ & $29.02 \%$ & $29.02 \%$ & $29.02 \%$ & $29.02 \%$ & $29.02 \%$ & $29.02 \%$ & $29.02 \%$ & $29.02 \%$ & $29.02 \%$ & $29.02 \%$ \\
\hline $\mathrm{F}$ & 13.78 & 13.73 & 13.68 & 13.64 & 13.59 & 13.54 & 13.49 & 13.45 & 13.40 & 13.35 & 13.30 & 13.26 \\
\hline $\mathrm{K}$ & 13.78 & 13.73 & 13.68 & 13.64 & 13.59 & 13.54 & 13.49 & 13.45 & 13.40 & 13.35 & 13.30 & 13.26 \\
\hline $\mathrm{P}$ & 0.4603 & 0.4587 & 0.4571 & 0.4555 & 0.4539 & 0.4523 & 0.4507 & 0.4491 & 0.4475 & 0.4460 & 0.4444 & 0.4428 \\
\hline interest rate & $45.23 \%$ & $45.23 \%$ & $45.23 \%$ & $45.23 \%$ & $45.23 \%$ & $45.23 \%$ & $45.23 \%$ & $45.23 \%$ & $45.23 \%$ & $45.23 \%$ & $45.23 \%$ & $45.23 \%$ \\
\hline
\end{tabular}

Table 8 Commodity Linked Operating Loan Payment Schedule

\begin{tabular}{|c|c|c|c|c|c|c|c|c|c|c|c|c|}
\hline $\begin{array}{l}\text { beginning } \\
\text { outstanding } \\
\text { loan }\end{array}$ & 6000.0 & 5339.6 & 4542.3 & 3371.5 & 6708.8 & 10207.1 & 12188.9 & 9915.3 & 7929.6 & 6406.4 & 9452.1 & 10198.4 \\
\hline $\begin{array}{l}\text { option } \\
\text { covered }\end{array}$ & $\$ 21.02$ & $\$ 18.71$ & $\$ 15.91$ & $\$ 11.81$ & $\$ 23.50$ & $\$ 35.76$ & $\$ 42.70$ & $\$ 34.74$ & $\$ 27.78$ & $\$ 22.45$ & $\$ 33.12$ & $\$ 35.73$ \\
\hline Interest paid & 226.17 & 201.27 & 171.22 & 127.09 & 252.88 & 384.75 & 459.45 & 373.75 & 298.90 & 241.49 & 356.29 & 384.42 \\
\hline
\end{tabular}


These twelve at the money option prices are calculated by Black-Scholes model, with brownie motion generated futures price as underlying price, as shown in Table 9. The average of these 12 options price $\$ 1.116864981$ is substitute to equation 21 to compute the interest rate. As displayed in Table 10, Goal-Seek function in excel is used to equate the left-hand side and right-hand side of equation 21 . The result the interest rate is $4.66 \%$ compare with $3.75 \%$ for normal mortgage.

The repayment of commodity linked mortgage each moth is shown in Table 11, for comparison, the repayment of a normal mortgage is also exhibited in Table 11. At the end of the $1^{\text {st }}$ moth, futures price falls to 13.19 , the option expires in-the -money, the hedge ratio is $\mathrm{A} / \mathrm{K}=1141.31 / 13.78=82.82$ and the option payout is $82.82 \times$ $\max (13.78-13.19,0)=48.62$, the farmer will repay 1234.09-48.62=1185.41, compared with $\$ 1141.31$ for the original mortgage; when there is large price decline, for example in the $12^{\text {th }}$ month where price declines to 9.22 , the option pays out $\$ 378.05$ and the farmer only need to repay $\$ 855.98, \$ 638$ less than he has to pay in a regular mortgage; when in good years where milk prices increase above $\$ 13.78$, farmer will pay the full annuity of $\$ 1,234.03$

\subsection{Other data sources and assumptions}

For consistency, we made the following assumptions for the farm model.

1. During the 3 year period that we implement the commodity linked credit, the herd size is steady, with constant number of cows and heifers on farm;

2. No new investments in machinery, buildings and livestock are made during this period; 
Table 9 Pricing of Option for Commodity Linked Mortgage

\begin{tabular}{|c|c|c|c|c|c|c|c|c|c|c|c|c|}
\hline time to maturity & $1 / 12$ & $1 / 6$ & $1 / 4$ & $1 / 3$ & $5 / 12$ & $1 / 2$ & $7 / 12$ & $2 / 3$ & $3 / 4$ & $5 / 6$ & $11 / 12$ & 1 \\
\hline volatility of futures & $29.02 \%$ & $29.02 \%$ & $29.02 \%$ & $29.02 \%$ & $29.02 \%$ & $29.02 \%$ & $29.02 \%$ & $29.02 \%$ & $29.02 \%$ & $29.02 \%$ & $29.02 \%$ & $29.02 \%$ \\
\hline current futures price & 13.78 & 13.78 & 13.78 & 13.78 & 13.78 & 13.78 & 13.78 & 13.78 & 13.78 & 13.78 & 13.78 & 13.78 \\
\hline strike price on option & 13.78 & 13.78 & 13.78 & 13.78 & 13.78 & 13.78 & 13.78 & 13.78 & 13.78 & 13.78 & 13.78 & 13.78 \\
\hline put premium & 0.460 & 0.650 & 0.796 & 0.919 & 1.026 & 1.124 & 1.213 & 1.296 & 1.373 & 1.447 & 1.516 & 1.582 \\
\hline Average option price & & & & & & 1.11 & 981 & & & & & \\
\hline
\end{tabular}

Table 10 Interest Rate Calculation for Commodity Linked Mortgage

\begin{tabular}{|l|r|l|r|}
\hline Mortgage & & loan amount & 577,500 \\
\hline $\mathrm{rm}$ & $3.75 \%$ & length & 240 \\
\hline $\mathrm{rm}^{\prime}$ & $4.66 \%$ & risk free rate & $0.47 \%$ \\
\hline lefthand & 155.9929314 & & \\
\hline righthand & 155.9929369 & & \\
\hline 1-r & $-5.51194 \mathrm{E}-06$ & & \\
\hline
\end{tabular}




\section{Table 11 Comparison of Repayment Schedule for Normal Mortgage and CLM}

\begin{tabular}{|c|c|c|c|c|c|c|c|c|c|c|c|c|c|}
\hline & & 1 & 2 & 3 & 4 & 5 & 6 & 7 & 8 & 9 & 10 & 11 & 12 \\
\hline \multirow{3}{*}{ original } & principal & $\$ 539.75$ & $\$ 541.43$ & $\$ 543.13$ & $\$ 544.82$ & $\$ 546.53$ & $\$ 548.23$ & $\$ 549.95$ & $\$ 551.67$ & $\$ 553.39$ & $\$ 555.12$ & $\$ 556.85$ & $\$ 558.59$ \\
\hline & interest & 601.56 & 599.88 & 598.18 & 596.49 & 594.78 & 593.08 & 591.36 & 589.64 & 587.92 & 586.19 & 584.46 & 582.72 \\
\hline & annuity & $1,141.31$ & $1,141.31$ & $1,141.31$ & $1,141.31$ & $1,141.31$ & $1,141.31$ & $1,141.31$ & $1,141.31$ & $1,141.31$ & $1,141.31$ & $1,141.31$ & $1,141.31$ \\
\hline \multirow{6}{*}{ CLM } & $\mathrm{F}$ & 13.19 & 12.81 & 12.01 & 11.55 & 10.63 & 10.80 & 10.79 & 11.42 & 10.58 & 10.03 & 9.45 & 9.22 \\
\hline & $\begin{array}{l}\text { option } \\
\text { covered } \\
\end{array}$ & 48.62 & 79.98 & 146.30 & 185.08 & 260.87 & 246.83 & 247.80 & 195.61 & 265.08 & 310.59 & 358.24 & 378.05 \\
\hline & principal & 487.27 & 489.16 & 491.06 & 492.96 & 494.88 & 496.79 & 498.72 & 500.66 & 502.60 & 504.55 & 506.51 & 508.47 \\
\hline & interest & 746.76 & 744.86 & 742.97 & 741.06 & 739.15 & 737.23 & 735.30 & 733.37 & 731.43 & 729.48 & 727.52 & 725.55 \\
\hline & total & $1,234.03$ & $1,234.03$ & $1,234.03$ & $1,234.03$ & $1,234.03$ & $1,234.03$ & $1,234.03$ & $1,234.03$ & $1,234.03$ & $1,234.03$ & $1,234.03$ & $1,234.03$ \\
\hline & actual & $1,185.41$ & $1,154.04$ & $1,087.72$ & $1,048.95$ & 973.16 & 987.20 & 986.22 & $1,038.41$ & 968.95 & 923.44 & 875.78 & 855.98 \\
\hline
\end{tabular}


3. Fertilizer \& lime, seed \& plants and spray costs are estimated on dollar per acre bases; breeding costs, vet and medicine, supplies, other income and other expense are estimated on per cow bases ; utility cost is a function of level of milk produced ( per cwt. bases); these data are collected from Business Summary New York State 2008 by Wayne A. Knoblauch, Linda D. Putnam, Jason Karszes and Jessica Anderson;

4. Costs for fixed assets include property tax and insurance for land, depreciation, insurance; repair and tax for buildings; depreciation, insurance and repair for machinery; insurance for livestock;

5. Feed costs included hay, corn, soybean(protein), corn silage and mineral cost; dairy farmers will sell extra feeds when there are surplus and buy feeds when there are deficit between produced by farmland and required by cows and heifers at market price;

6. One full time equivalent worker provides 2760 hours of labor each year, as assumed in 'projecting cash flows on dairy farms' by Eddy L.LaDue;

7. Fuel and oil cost are on dollar per acre bases with adjust of relative cost factor to corn silage, Hay and dairy cows, as suggested by Eddy L.LaDue;

8. Cropland value per acre is obtained from USDA-NASS, as exhibited in Figure 8 , NY crop land value is $\$ 2,200$ per acre. Inflation rate is set at $2 \%$ per year. http://www.nass.usda.gov/Charts and Maps/Land Values and Cash Rents/c $\underline{\text { rop_value map.asp }}$

9. The reduction in principal repayment from option excise is regarded as net income for dairy farmers and will go through operating cash flow.

10. It is assumed the US options market is efficient and liquid. There is no arbitrage opportunity for option and futures. 
2009 Copland value by State

Dollars per mae 8 Feroent Change fom 2008

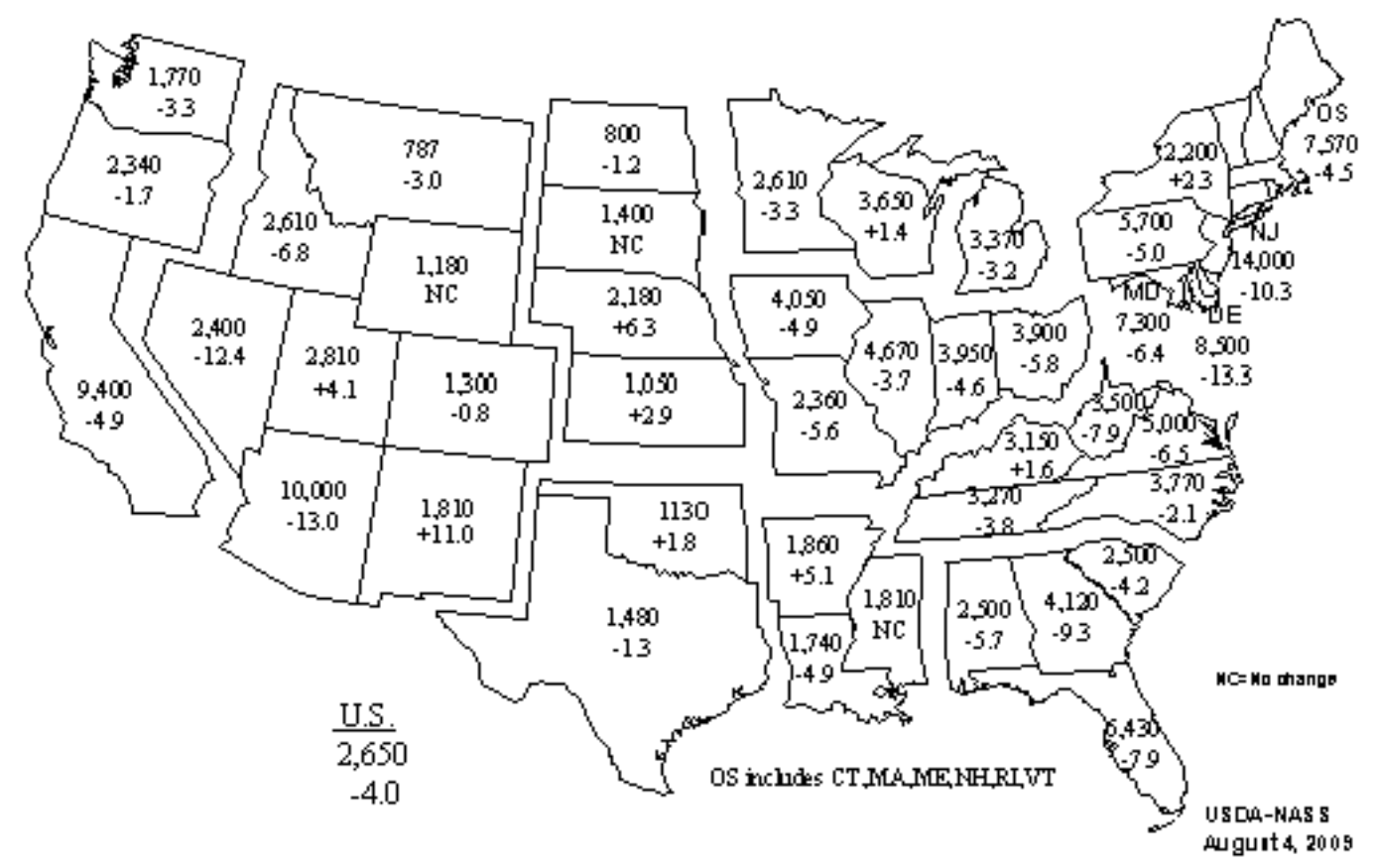

Figure 8 Crop Land Value per Acre by State 2009 


\section{Chapter 4}

\section{RESULTS AND DISCUSSION}

\subsection{Results for small dairy farm}

Commodity linked credit in this thesis is designed to relieve the financial stress faced by small and high debt farmers. Thus, the representative farm is set with a herd of 50 cows and with $\$ 5,500 \mathrm{debt} / \mathrm{cow}$. Three financial statement spreadsheets, the first the base model with regular loan and mortgage, the second the model with commodity linked credit, the third the model with commodity linked loan (these three models are identical in all other aspects) are iterated simultaneously with the same seeds for generating random numbers. All results are based on 20,000 iterations. Farm financial and solvency data are compared among the three models below to scrutinize the effect of CLM and CLO on dairy farms.

\subsubsection{Sales}

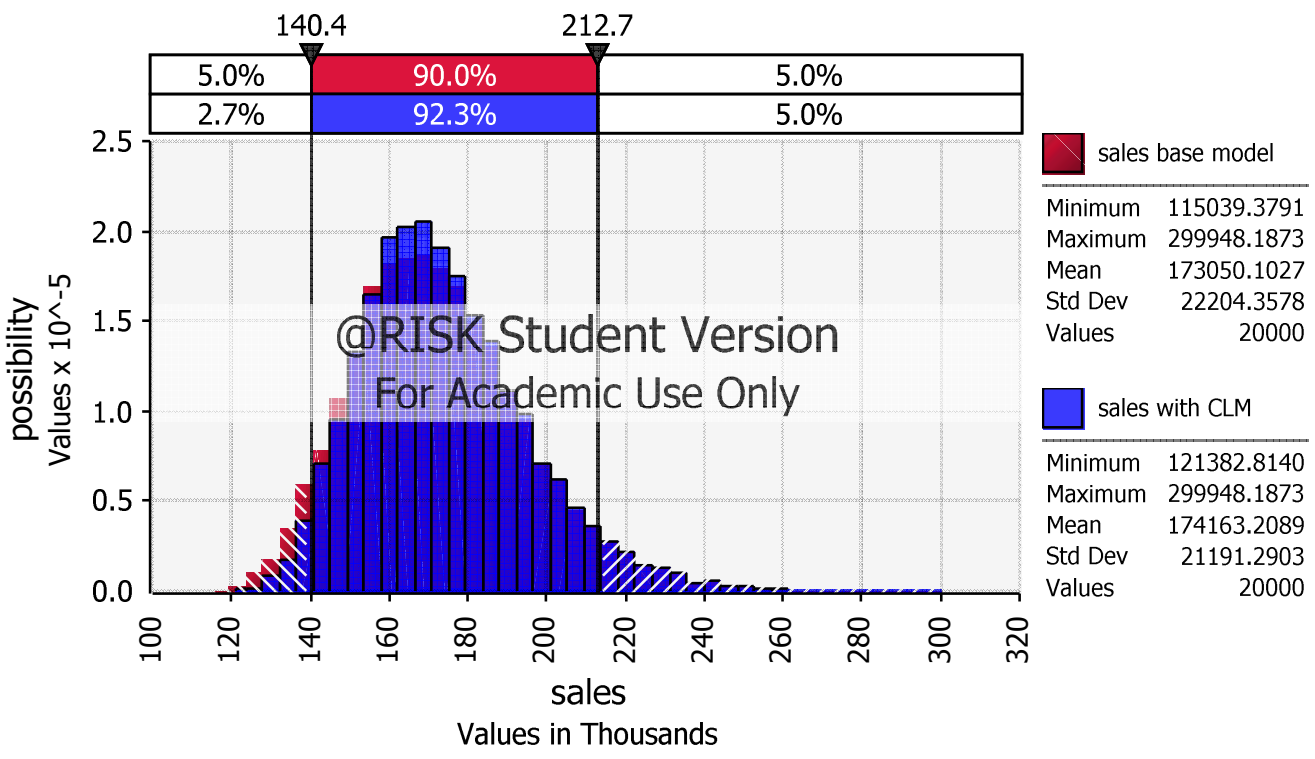

Figure 9 Sales Distribution of Base Model and with CLM 


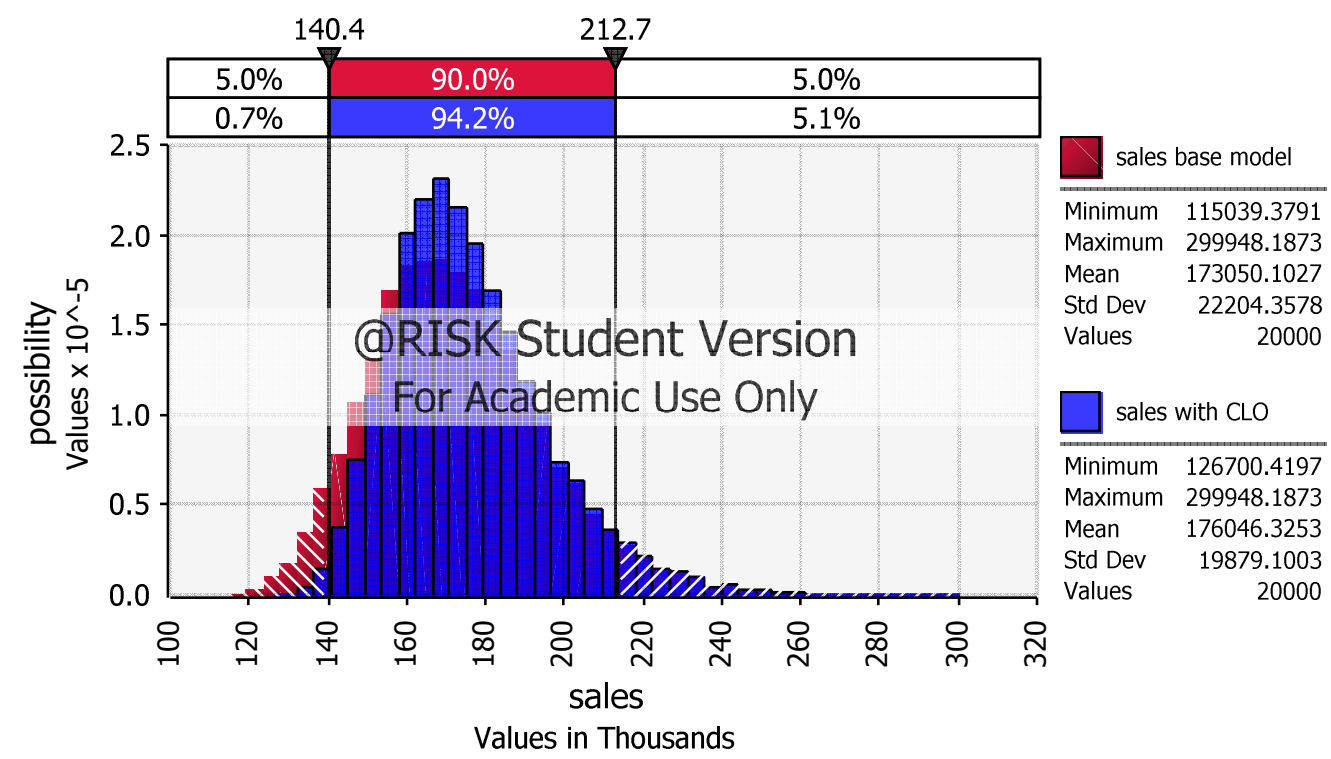

Figure 10 Sales Distribution for Base and CLO

The red bar in Figure 9 and Figure 10 is the distribution of sales for the base model. Variance in sales is a measure of business risks faced by dairy farmers. As stated in Chapter 2, such business risk, reflected as the uncertainty in operating cash flow, is caused by milk price fluctuation. The blue bar in Figure 9 represents the distribution of sales for farm with CLM. When milk price falls, the imbedded option in CLM expire in the money and the payout compensates the decrease in sales receipt. Thus, the possibilities for low sales outcome are reduced, as could be seen by the lower value of distribution density with sales below $\$ 160,000$ compare to the based model. Meanwhile, the upside potential for high sales receipt is not affected by the imbedded option. This results in a skew to the right and a reduction in variance in the distribution of sales for farm with CLM.

The effect of reduction in variance of milk sales for CLO is more significant, as the distribution of CLO is more skewed to the right in Figure 10. Such difference is because unlike the hedge ratio of CLM, which is fixed, the hedge ratio for CLO is 
adjusted to the change in loan level each month, allowing more protection from the option, further reducing the variance in sales.

\subsubsection{Total expense}

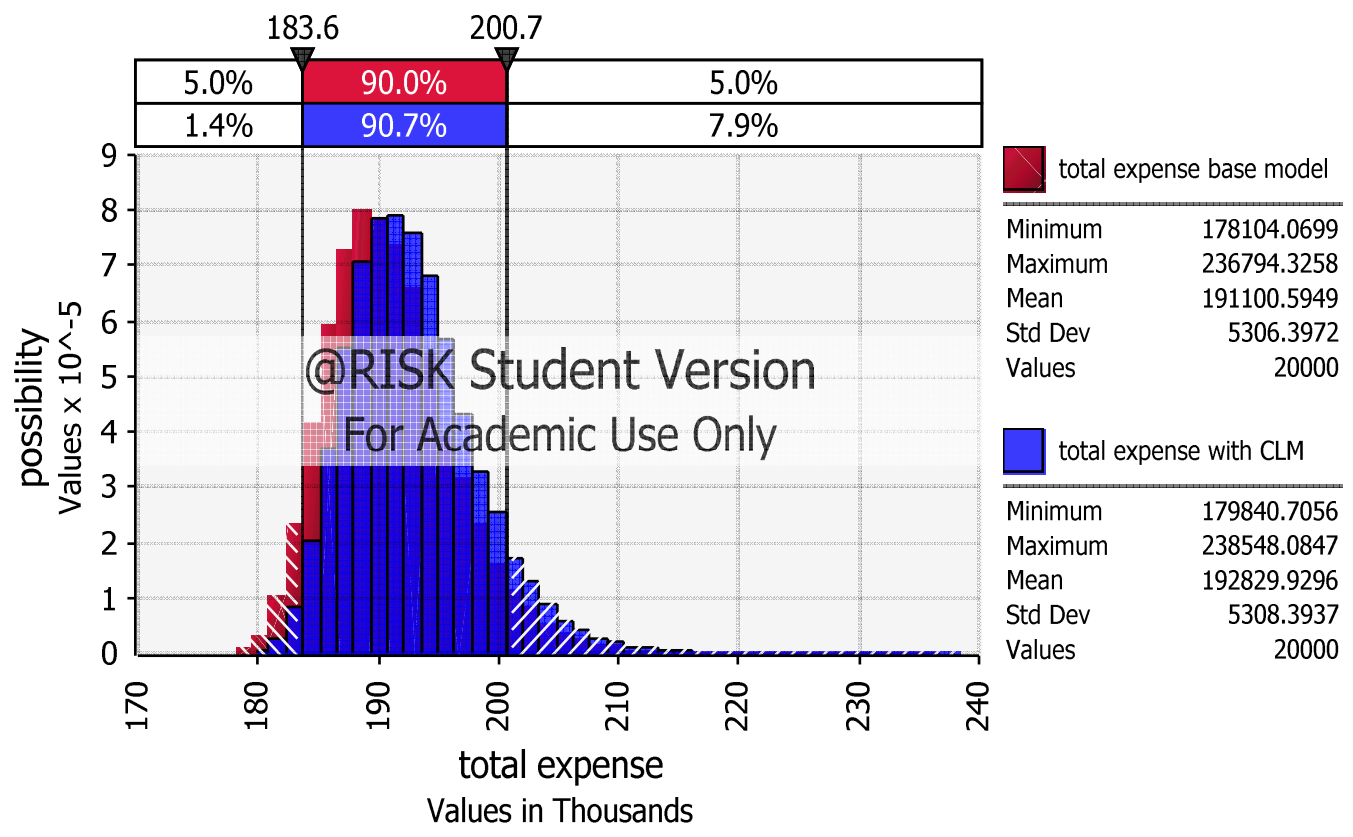

Figure 11 Total Expense Distribution of Base and CLM

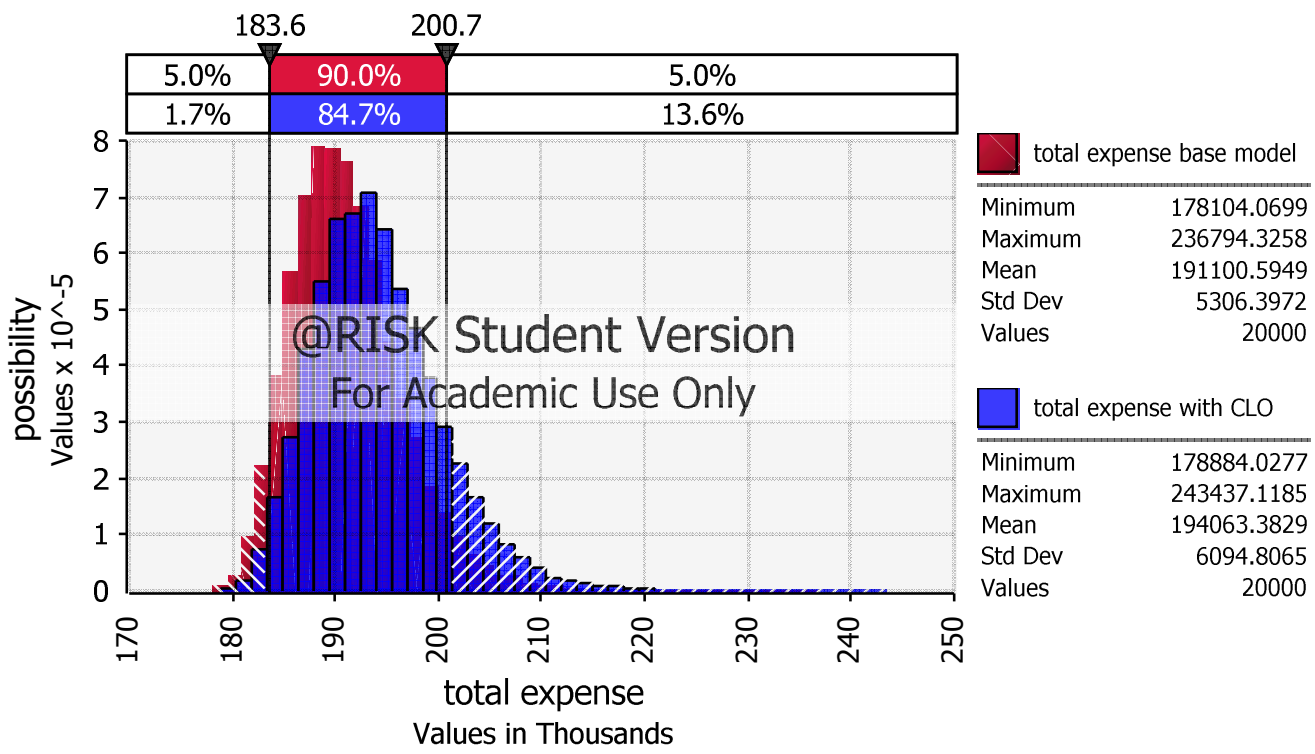

Figure 12 Total Expense Distribution of Base and CLO 
Figure 11 compares the distribution of total expense for base farm and farm with CLM, the variance in total expense is due to fluctuation in corn and soybean costs. The shapes of the two distributions are essentially the same except the distribution of farm with CLM shifted parallel rightwards. This is because the interest repayment is with certainty but higher for CLM to compensate for the downside protection provided by imbedded options. By the same token, the distribution of expense for farm with CLO also shifted rightwards, as exhibited in Figure 12.

\subsubsection{Net Income}

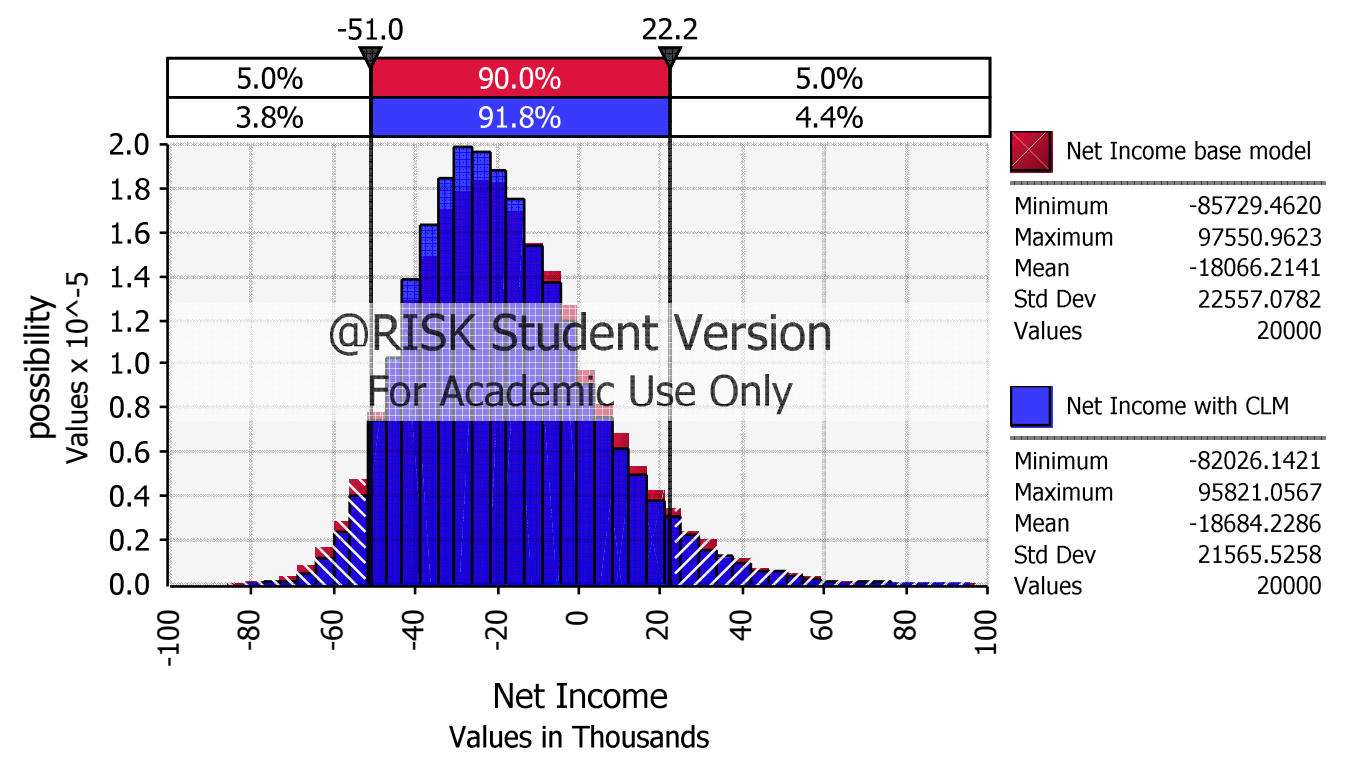

Figure 13 Distribution of Net Income for Base and CLM 


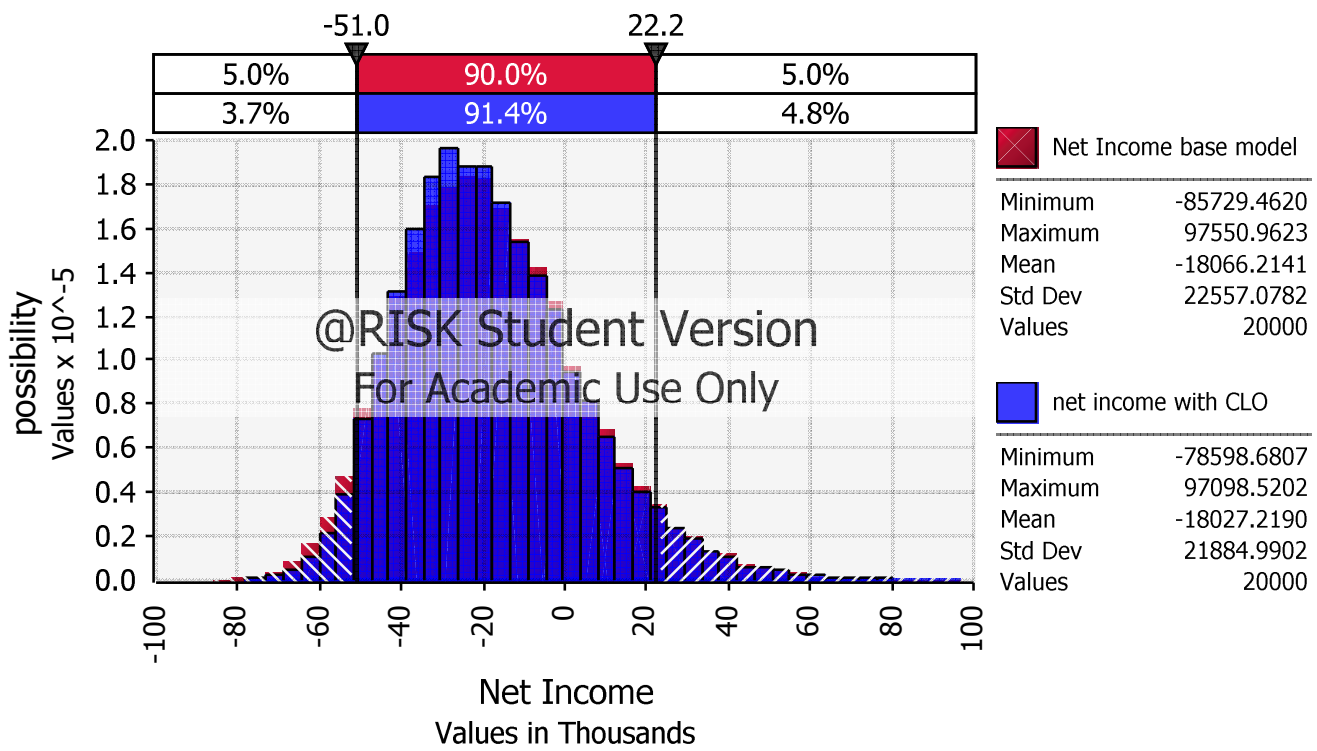

Figure 14 Distribution of Net Income for Base and CLO

Combining the effect of sales and expense, the distribution of net income can be inferred.Net Income is defined as the residual income by adding total sales and subtracting total expenses before distributing to family uses. Figure 13 shows the distribution of base farm and farm with CLM. The mean net income is the same because on average, the expected option payout accounted in sales should be offset by higher interest rate premium in interest expense for CLM. These two terms should cancel out in net income. The possibility of extreme low net income outcome, measured by the area below the blue bar, is lower than the possibility of extreme low net income outcome in the base model, which is represented by the area under the red bar). In other words, the downside risk is reduced by CLM. However, the potential for higher net income is also reduced because of the higher interest expense required by CLM. the overall effect is a reduction in variance in net income and thus a reduction in business risk by implementing CLM. 
Figure 14 shows that CLO also has the effect of reducing business risk by truncating the downside and upside of net income. Standard deviation for net income of farms with CLO is 21,921 , smaller than the standard deviation of base farm.

4.1.4 Debt coverage ratio versus option payout

One important measurement of solvency for dairy farms is debt coverage ratio, which is expressed as Debt Coverage Ratio $=\frac{\text { Net Income }+ \text { Depreciation }+ \text { Interest expens }}{\text { Scheduled debt repyament }}$

The debt coverage ratio measures the ability of dairy farms to generate operating cash to cover debt principal and interest repayment. A debt coverage ratio of below 1 indicates there is not enough cash to cover cost. Thus, debt coverage ratio is a good indicator of the financial risks.

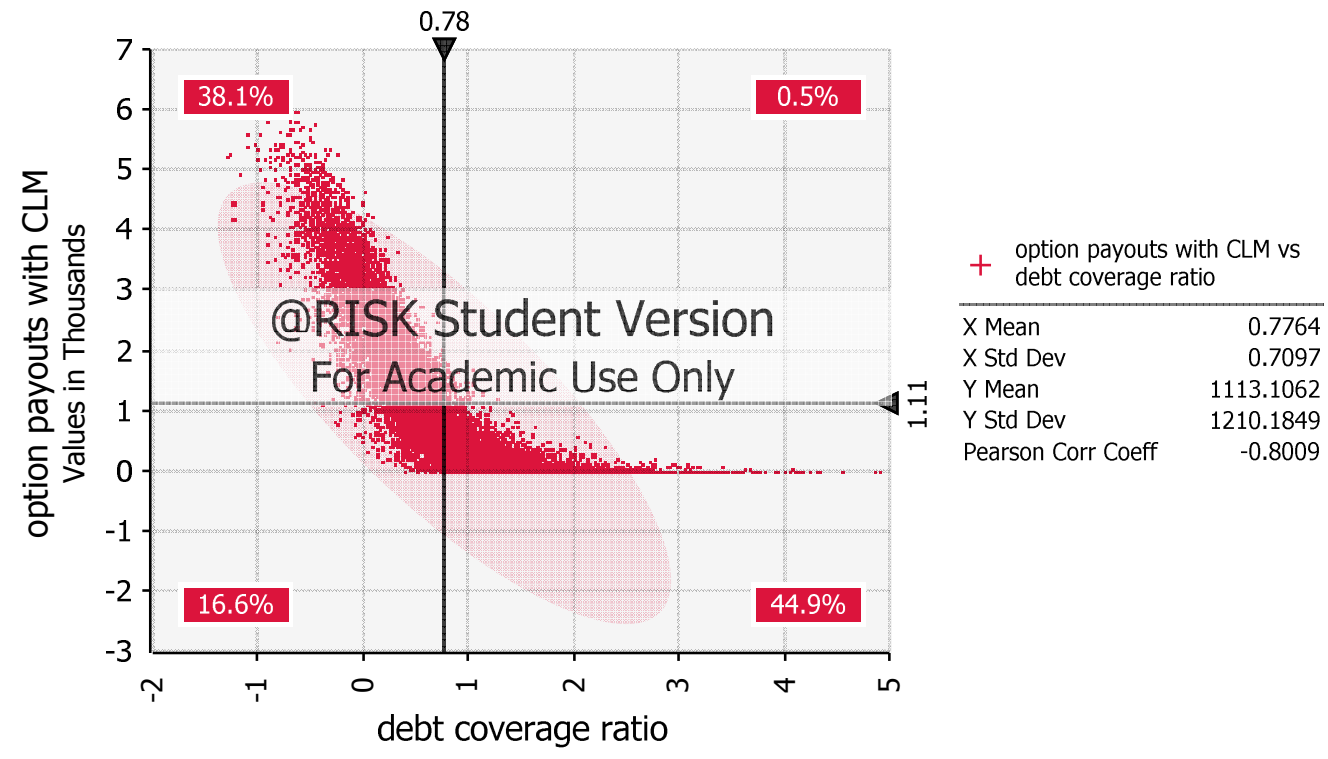

Figure 15 Debt Coverage Ratio vs. Option Payouts for CLM 


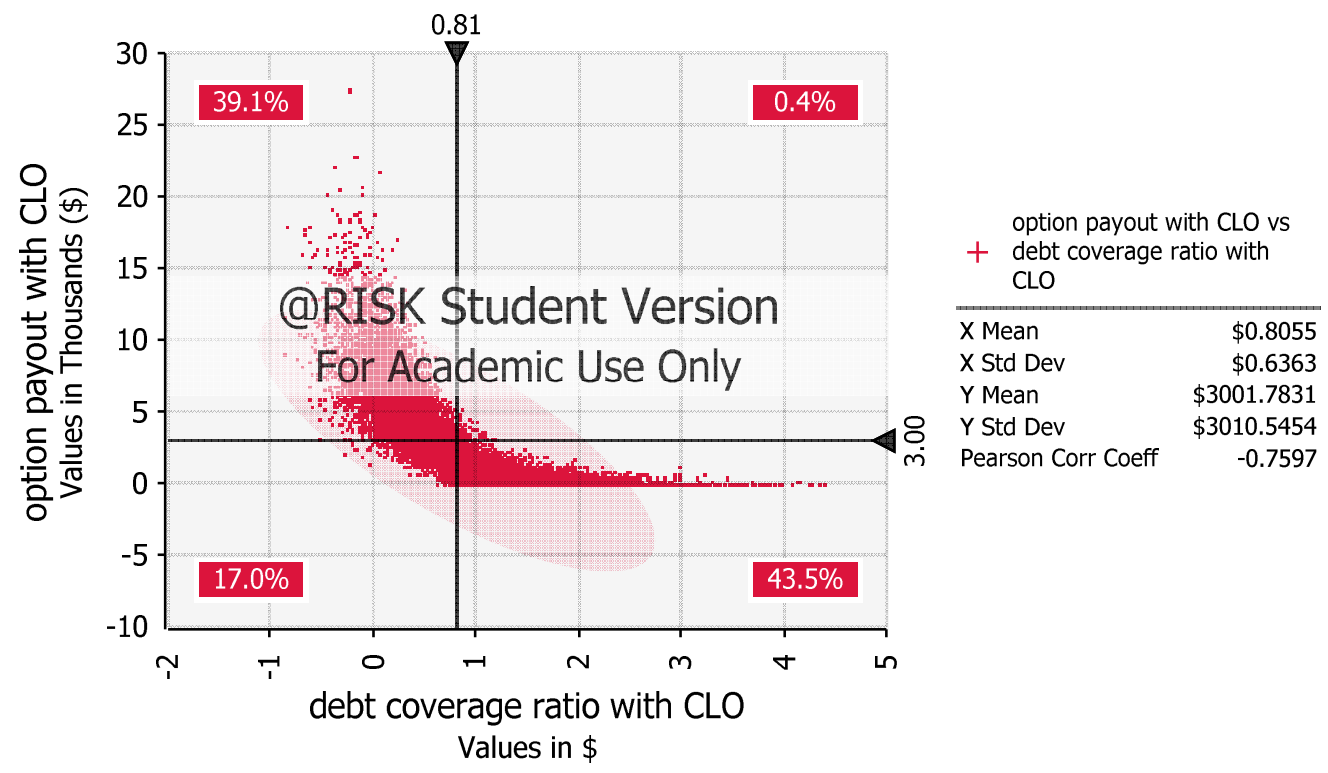

Figure 16 Debt Coverage Ratio vs. Option Payouts for CLO

Figure 15 is the correlation between option payouts and debt coverage ratio for farm with CLM. When milk prices are high, farmers generate sufficient cash flow to cover their debt, with debt coverage ratio greater than 1. Meanwhile, the imbedded option expires out of the money and the commodity linked mortgage functions the same as regular mortgage. The benefit of commodity linked mortgage manifests when milk prices fall, farmers generate less free cash flow to cover scheduled debt repayment, debt coverage ratio falls below 1, increases the financial risk; meanwhile, the imbedded option starts to expire in the money. The more debt coverage ratio goes below 1 as the milk price declines, the deeper the option is in the money and the higher the option payouts. Since the farmers only have to repay the scheduled repayment less the option payouts, they get more protection against increasing financial risks. It is as if writing a put option directly on debt coverage ratio. The width in debt coverage ratio for a given option payout is because debt coverage ratio is also influenced by other variables, e.g. feed cost fluctuation. These risks could not be hedged by CLM with imbedded option on class III milk. 
Displayed in Figure 16 is the correlation between option payouts and debt coverage ratio for farm with commodity linked operating loan. As in the case with commodity linked mortgage, the option pays more as debt coverage ratio goes farther below 1. Another observation is that the magnitude of the option payout from commodity linked operating loan is greater than that from commodity linked mortgage. This is because difference in the way of these two products is structured. The maximum option payout equals to the annuity and the loan principal for CLM and CLO respectively. Because of the time value, the annuity is significantly smaller than operating loan each period, so the hedge ratio is smaller for CLM, thus result in less option payouts compare to the option payouts of CLO.

\subsubsection{Return on assets}

Return on assets (ROA) is calculated as

$$
R O A=\frac{\text { Net Income }+ \text { Interest expens }}{\text { total assets }}
$$

Variance in ROA is a measure of business risk. The distributions of ROA for base farm and farm with CLM are exhibited in Figure 17. The red line represents the cumulative distribution of return on assets in the base model; the blue line represents cumulative distribution of return on assets with commodity linked credit. The areas under each line measure the total variance of return on assets. It could be seen that the area for model with CLM is smaller than the area for base model. Specifically, the area representing low ROA is smaller for model with CLM. such outcome is due to the effect of imbedded options that truncated the low ROA. We can infer from this graph that CLM reduced variance of return on assets and thus business risk.

Figure 18 is a comparison of the cumulative distribution of return on assets for base farm and farm with CLO. Again, the reduction in business risk is more significant compare with CLM because of the hedging ratio is greater for CLO. 


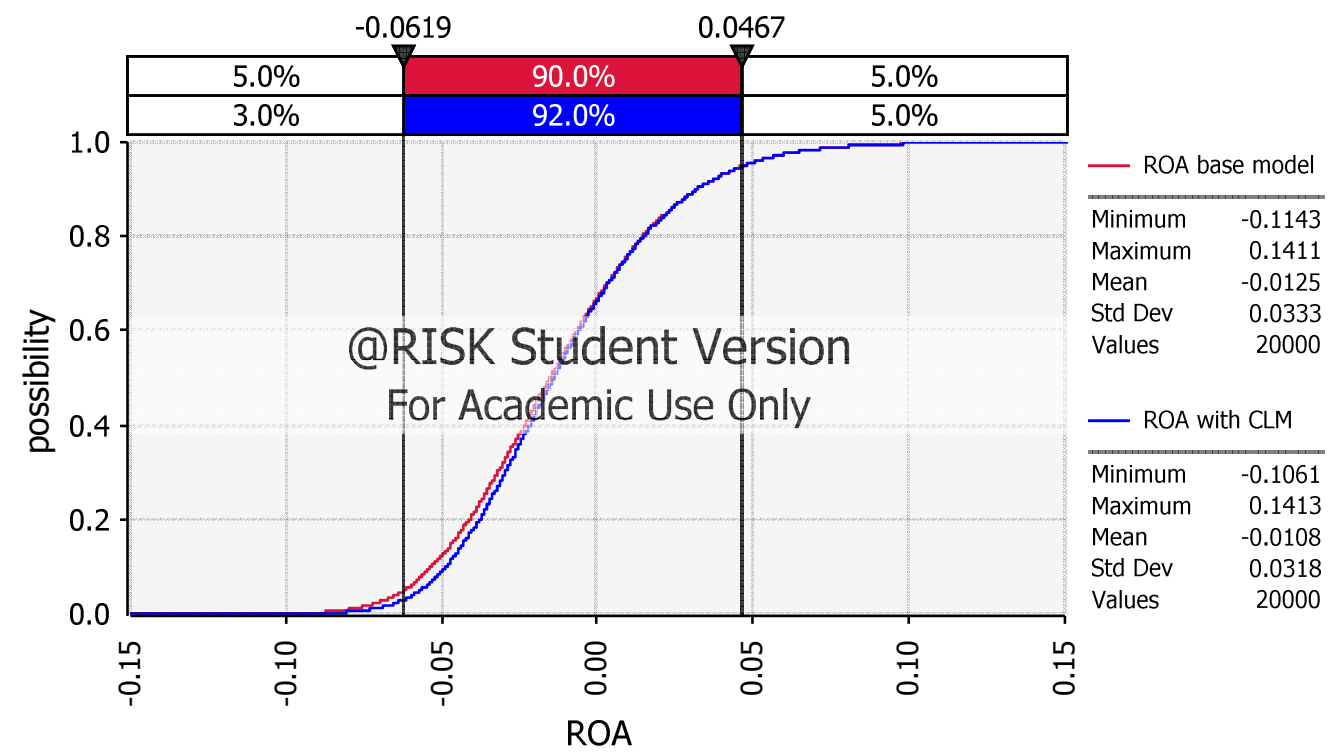

Figure 17 Cumulative Distribution of ROA for Base Farm and Farm with CLM

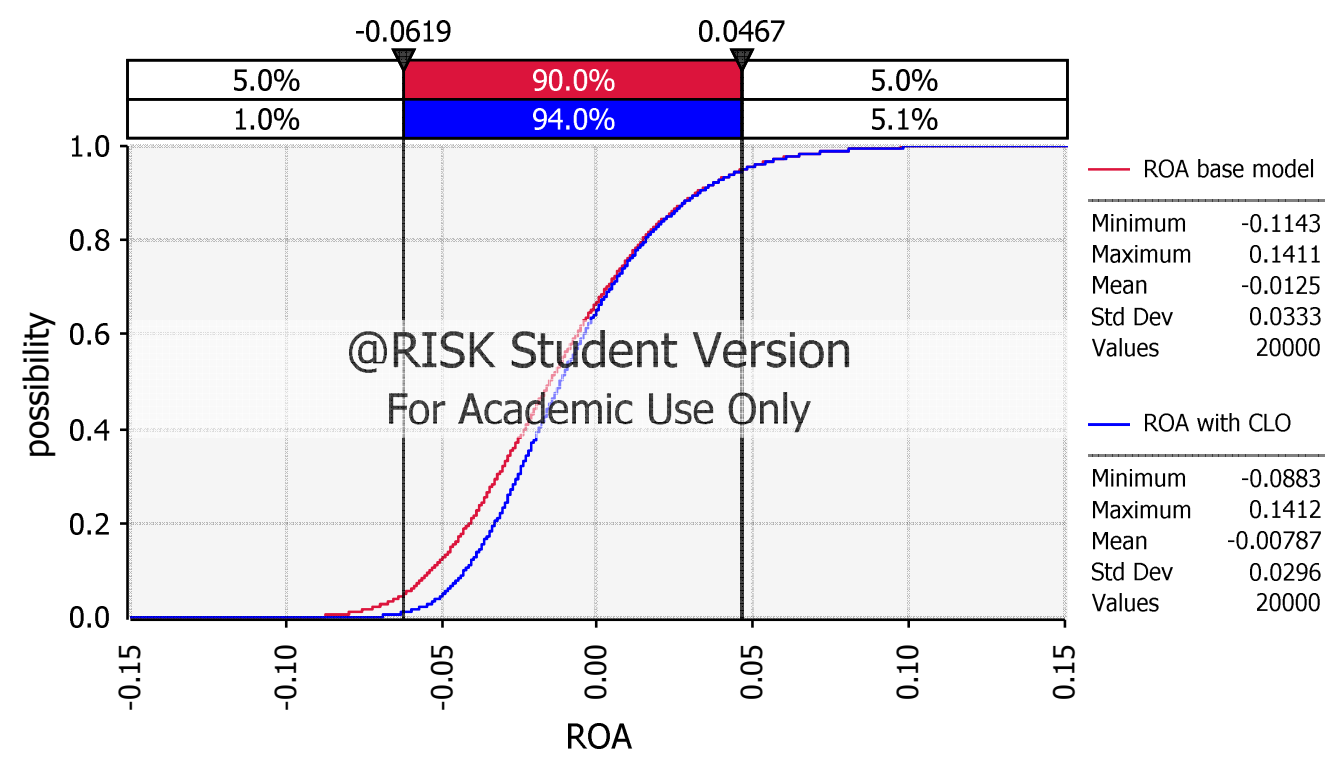

Figure 18 Cumulative Distribution of ROA for Base Farm and Farm with CLO 


\subsubsection{Return on equity}

Return on equity (ROE) is calculated as

$$
R O E=\frac{\text { Net Income }}{\text { total equity }}
$$

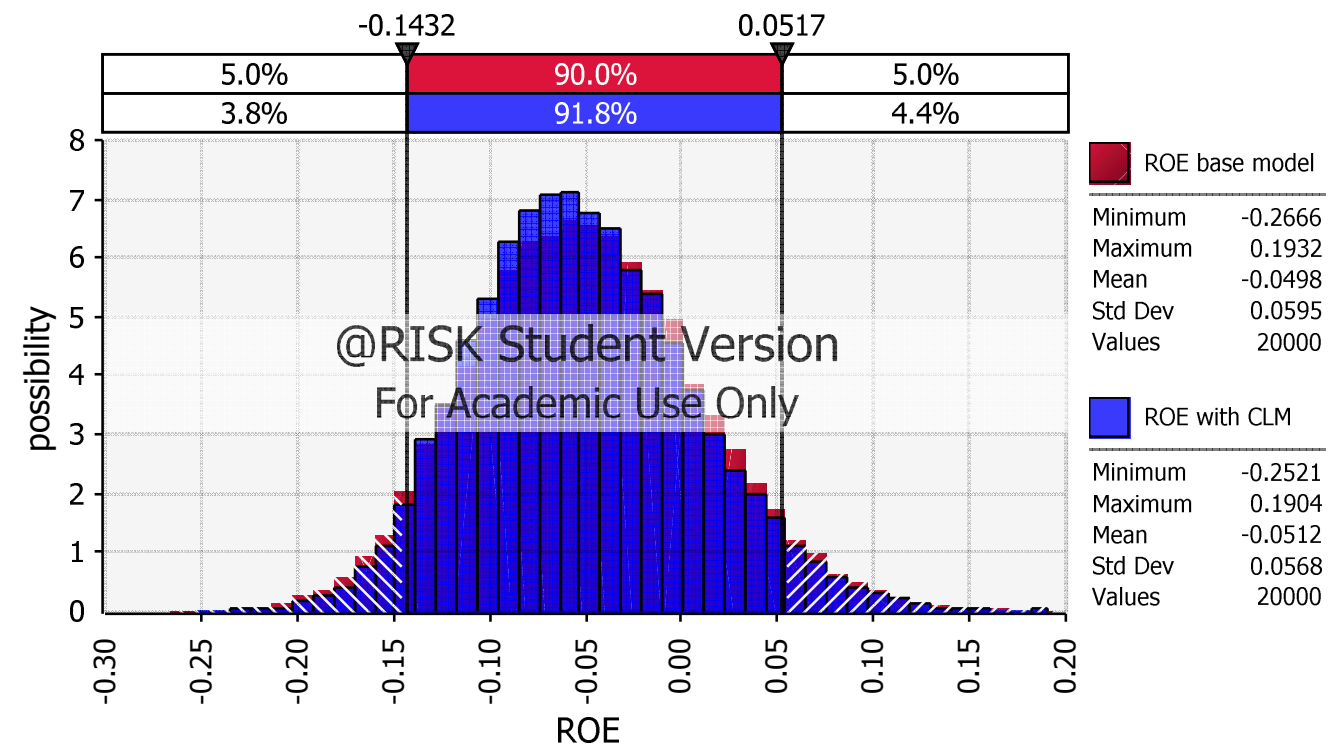

Figure 19 Distribution of ROE for Base Farm and Farm with CLM

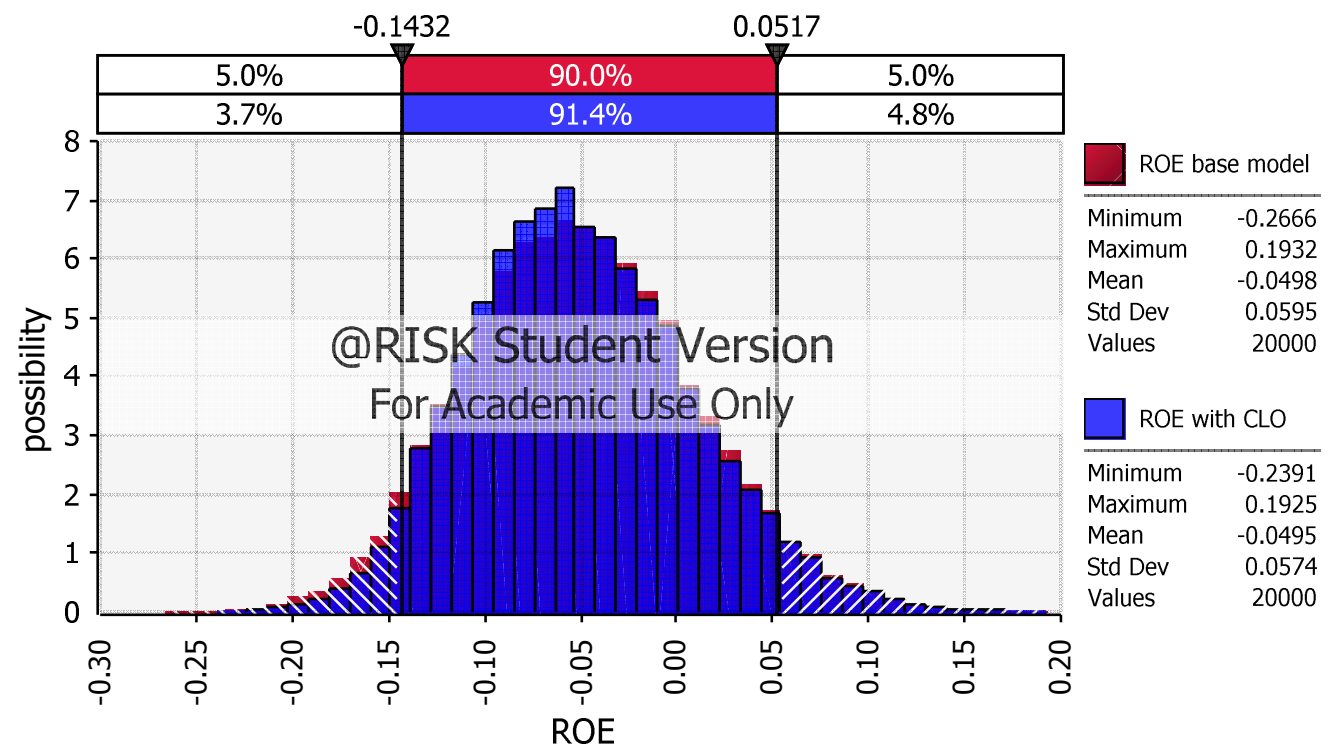

Figure 20 Distribution of ROE for Base Farm and Farm with CLO 
Total risk faced by the farm is captured by return on equity. The red bar in Figure 19 is the return on equity for base farm; the blue bar is the return on equity for

farm with CLM. With CLM, the possibility for low ROE is reduced but the possibility for high ROE is sacrificed because of higher interest rate charged. This is reflected by higher kurtosis (3.1107 vs. 3.0288) and lower standard deviation (0.0566 vs. 0.0594) for the distribution of ROE with CLM. CLO also has the effect of reducing total risks, as shown in Figure 20.

\subsection{Sensitivity analysis}

The results in 4.1 are based on farm with 50 cows and 100\% hedging ratio with at the money put options. Sensitivity analyses are conducted to examine the effect of commodity linked credit with lower hedging ratio or expanding herd size.

\subsubsection{Lower hedging ratio}

One important consideration is farmer may want to sacrifice part of the protection from imbedded option of commodity linked credit for a lower interest rate.

In this case, the effect of reducing the strike price to $80 \%$ of spot price for imbedded option in both commodity linked mortgage and commodity linked operating loan is examined (holding all other conditions the same as before). As the strike is adjusted to $80 \%$ of spot price, the interest rate premium decreased considerably. The interest for CLM is now $3.96 \%$ compare with $4.66 \%$ in the case of $100 \%$ hedging; the interest rate for CLO is $0.51 \%$ per month compare with $3.77 \%$. But the downside protection also becomes trivial. As displayed in Figure 21, the distributions of net income of base farm, measured by the bold red line, farm with commodity-linked mortgage(blue line)and farm with operating loan (green line) are indistinguishable. 


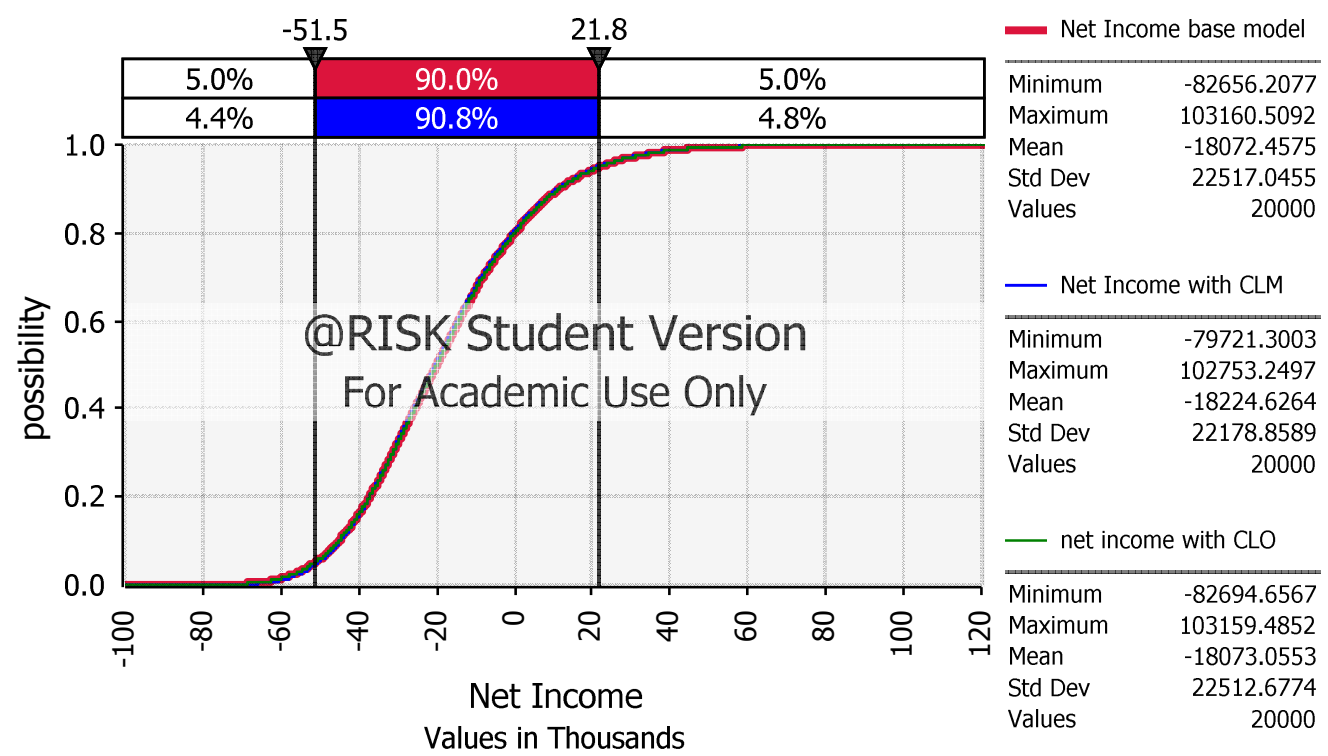

\section{Figure 21 Cumulative Distribution of Net Income for Base, CLM and CLO with $80 \%$ Hedge}

The reason for the convergence of net income distribution can be explained as follows. The new strike price, in this case $\$ 11.02$ is so low that the milk price has very low possibility of falling below the strike price and triggers the imbedded option payout. Therefore, when price plunged to below 13.78 but above 11.02 , less milk receipt due to low milk price is not mitigated by option payouts. The probability of protection is decreased. This is reflected in the cumulative distribution of sales. In both Figure 22 and Figure 23, the distribution of sales with CLM almost overlap with that of base farm, there is virtually no reduction in low revenue outcome. So a hedging ratio of above $80 \%$ is recommended for farmers who want to protect their downside risks. 


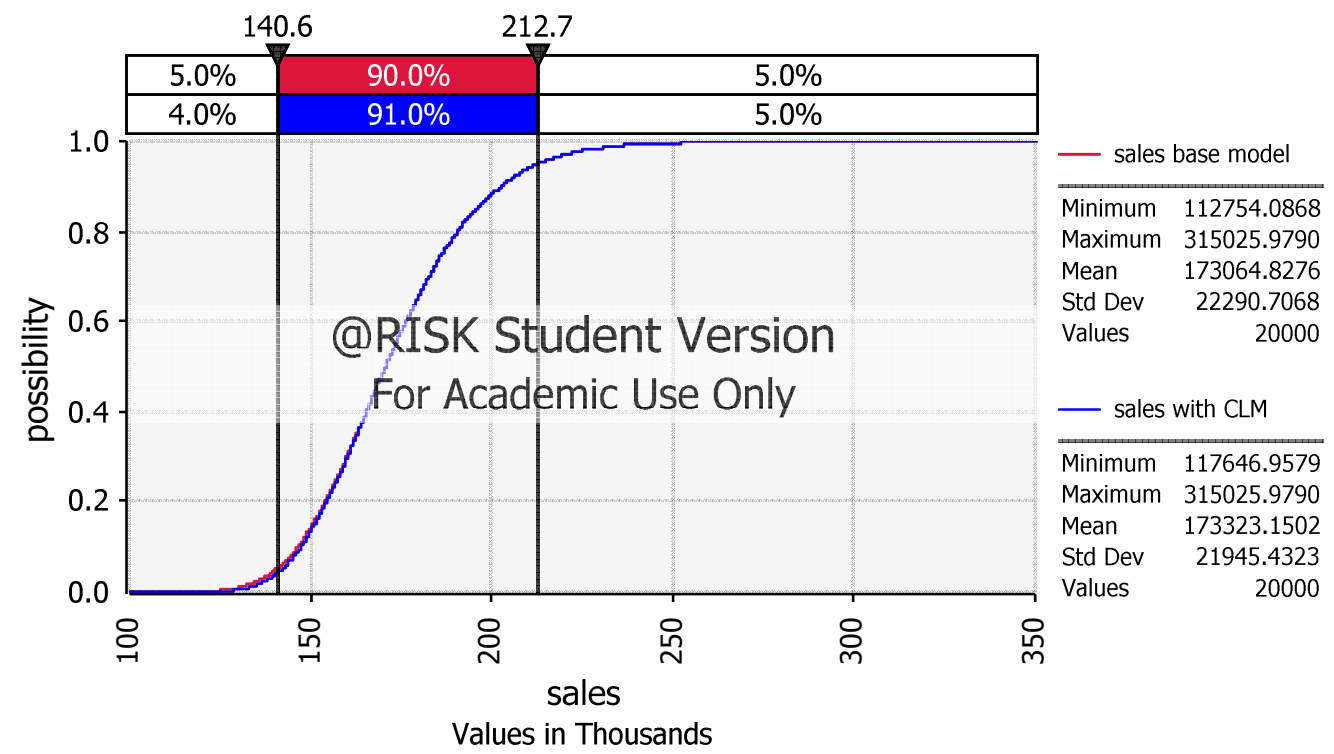

Figure 22 Cumulative Distribution of Sales for Base and with CLM, 80\% Hedge

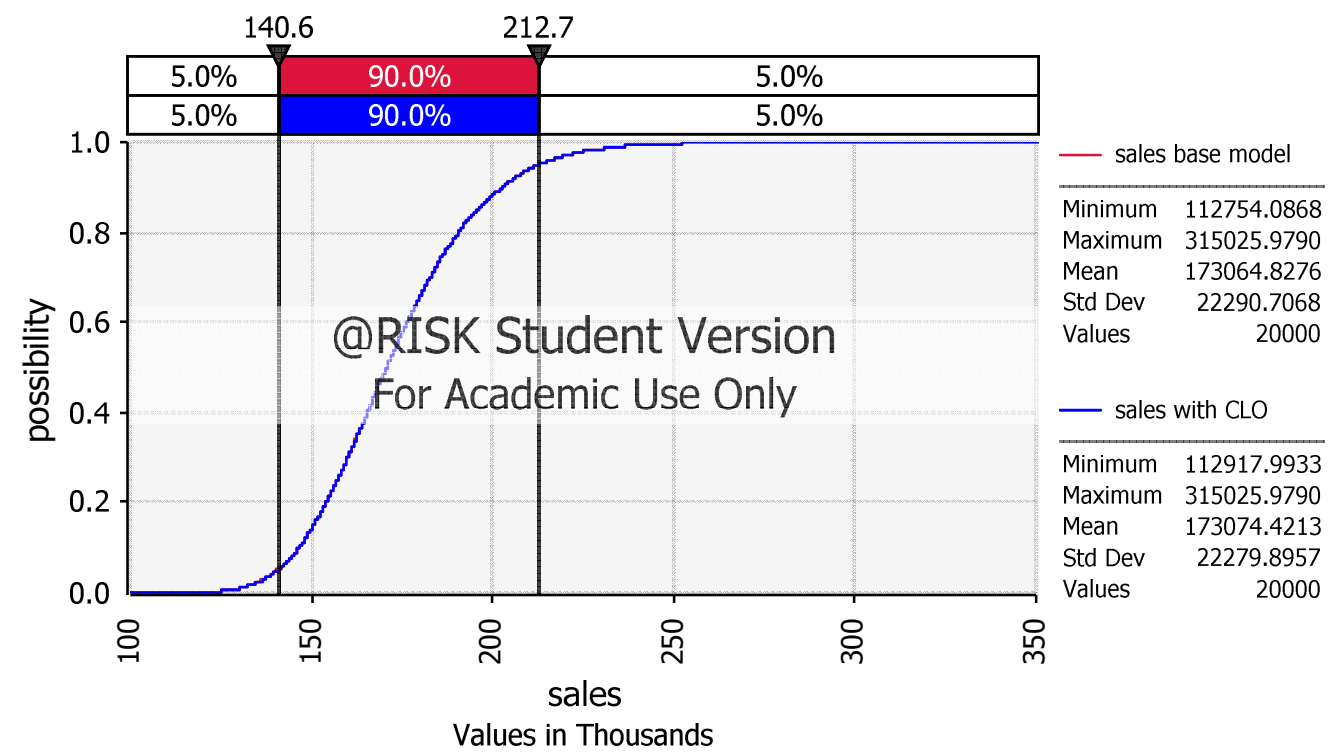

Figure 23 Cumulative Distribution of Sales for Base and with CLO, 80\% Hedge 


\subsubsection{Expanding herd size}

Commodity linked credit is designed to help small herd (less than 300 cows) dairy farms. Although it is assumed that farm faces constant scale of technology, e.g. the financial statement is scaled and commodity linked credit should operate the same independent of herd size. However, to be exact, the herd size is moderately expanded to 150 cows for the models in section 4.1. The imbedded options function the same as in models with 50 cows.

As exhibited in Figure 24 and Figure 25, imbedded option payouts for both CLM and CLO show high correlation with debt coverage ratio, the lower the debt coverage ratio, the higher the imbedded options payouts. For a given payout, the variance in debt coverage ratio is due to variance in feed cost, which is not hedged.

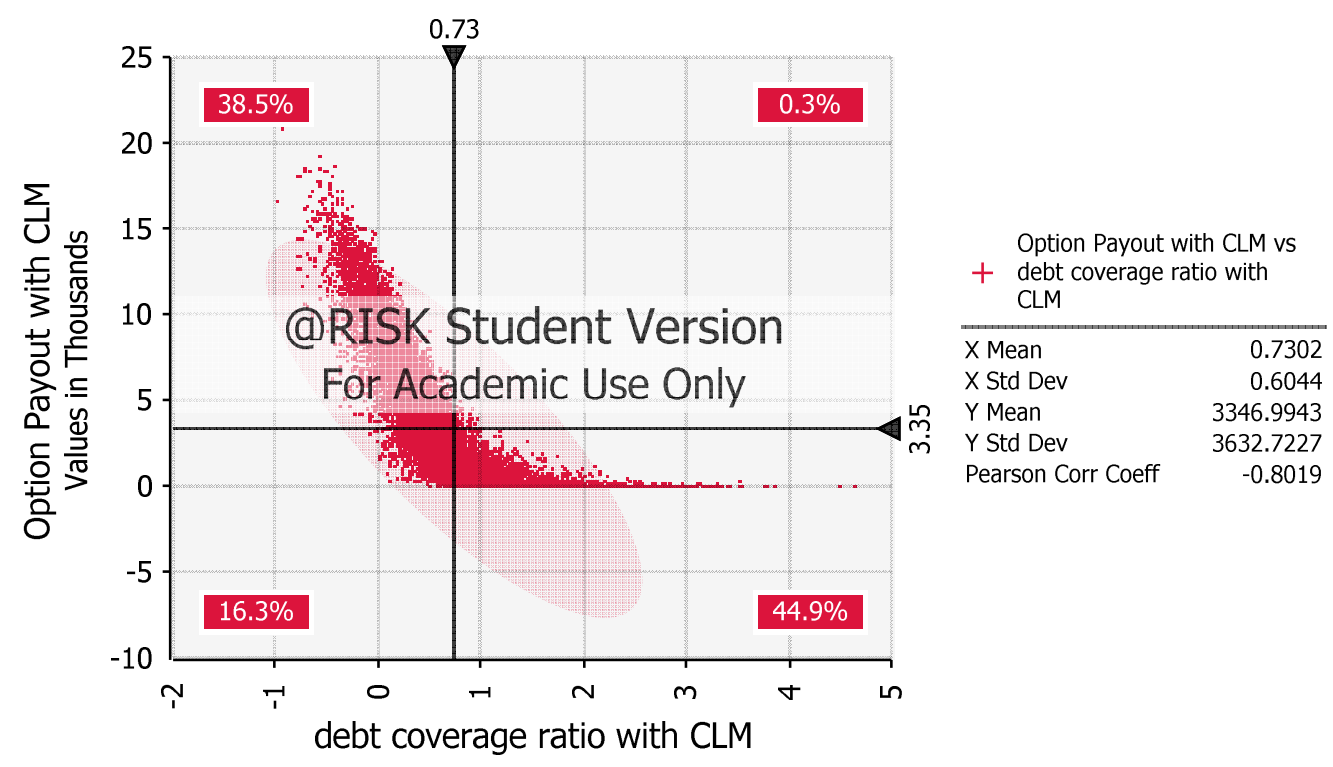

Figure 24 Option Payout vs. Debt Coverage Ratio of CLM for Herd Size of 150 


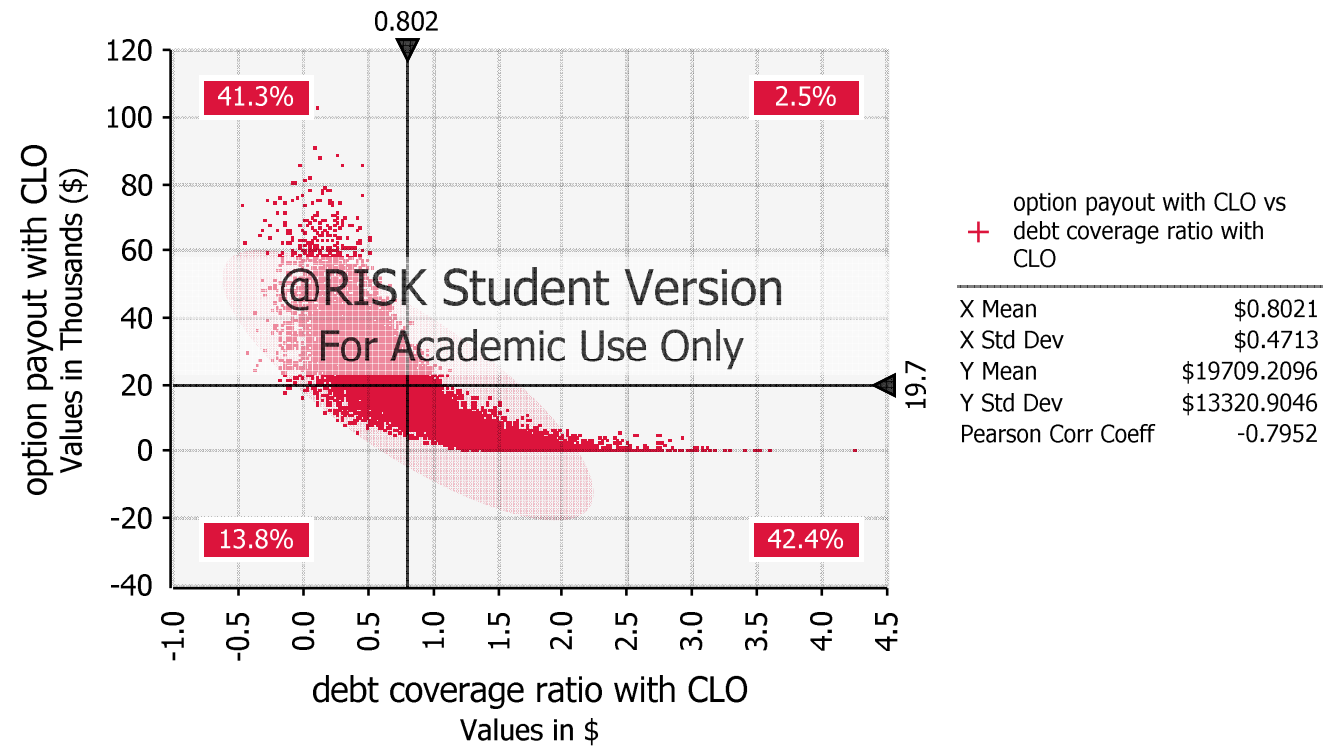

Figure 25 Option Payout vs. Debt Coverage Ratio of CLO for Herd Size of 150

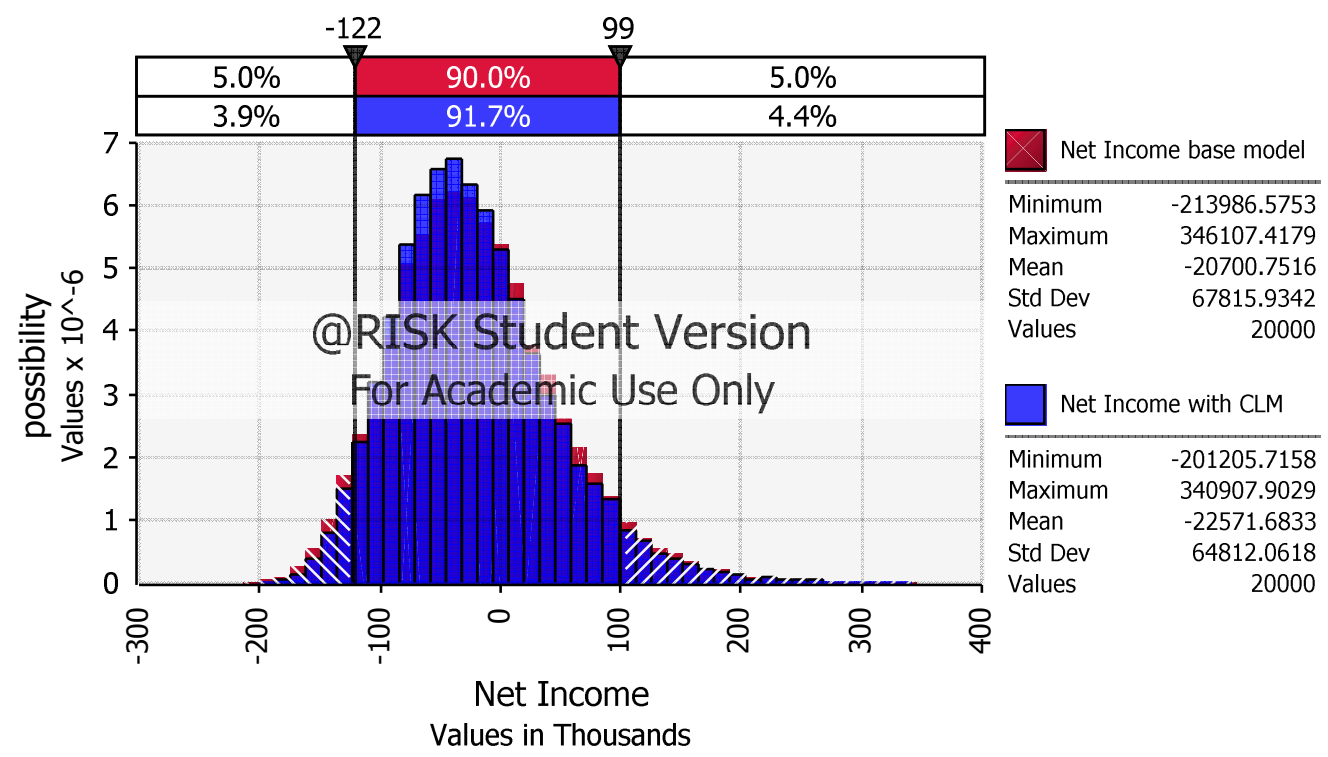

Figure 26 Distribution of Net Income for Base Model and CLM, 150 Cows 


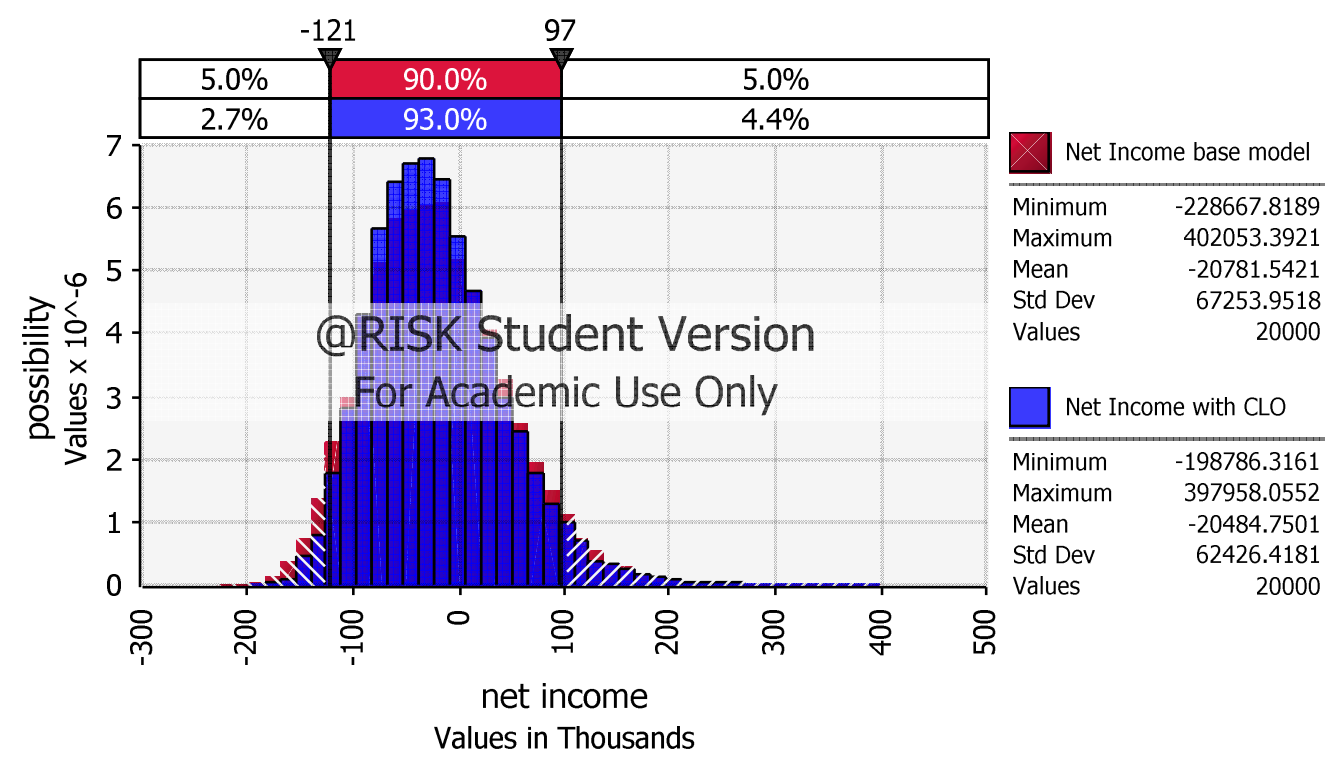

Figure 27 Distribution of Net Income for Base Model and CLO, 150 Cows

The variance in net income for farm with CLM is smaller, as demonstrated in Figure 26. Notice that the mean net income is off by around $\$ 2,000$ for base farm and farm with CLM. This is because the way farm with commodity linked mortgage is designed in this paper. The expected payoff for imbedded options in commodity linked mortgage should equal to the difference between the annuity repayments. With different interest rate, the portion of annuity attributed to principal and interest repayment are different for commodity linked mortgage and regular mortgage. This can be expressed as

$$
E[\max (K-P, 0)]=A^{\prime}-A=P^{\prime}-P+P^{\prime} r^{\prime}-P r
$$

Where $A^{\prime}, A$ are annuity for commodity linked mortgage and regular mortgage respectively;

$P^{\prime}, P$ are portion of annuity repayment attributed to principal repayment for CLM and regular mortgage; 
$P^{\prime} r^{\prime}, P r$ are portion of annuity repayment attributed to interest repayment for CLM and regular mortgage.

As option payoffs are counted as revenue, only the $P^{\prime} r^{\prime}-P r$ are counted in net income, the principal repayment difference $P^{\prime}-P$ will not go through liability not net income. Thus, the $\$ 2,000$ off is the difference in principal repayment.

\subsection{Future research}

Interest rate of commodity linked operating loan is calculated monthly because the imbedded option is bought every month in this paper. Thus, an agent may be required to monitor and to constantly adjust the hedging position of commodity linked loan. Methods to reduce such transaction costs could be considered.

Also, the risk that is being hedged in this paper is milk price risk. However, feed cost fluctuation could also increase business risk and financial risks of dairy farm. Thus, a commodity linked loan with joint option that hedges both the risk of milk price and feed cost price risks could be designed and implemented based on the model in this paper. 


\section{Chapter 5}

\section{SUMMARY AND CONCLUSION}

The overall objective of this thesis was to balance the financial and business risks faced by dairy farmers in NY State through the design and application of risk contingent credit. In this paper, the risk contingent credit refers to a suite of financial products with payoff schedules tied to the price of class III milk futures price.

To achieve this objective, a coordinated financial statement model of a typical dairy farm developed by University of Wisconsin is set up and modified in the following ways. 1) randomness in milk price received by dairy farmers are added to the model; 2) feed cost, e.g. corn and soybean prices are correlated with milk prices; 3) cyclicity in milk production per month is introduced into the model; 4) a line of credit to record the balance of operating loan is created.

After the modification is made, three spreadsheet of financial statement are set up; the first one, referred to as the base model, has regular mortgage and operating loan, the second one replaced the regular mortgage by commodity linked mortgage while holding all other inputs the same as in base model; the third model substitute the regular operating loan with commodity linked operating loan, holding all other inputs constant.

Monte Carlo simulation with 20,000 iterations is implemented to the three spreadsheets above (with the same seeds). From the results of the simulation, the following conclusions are reached.

1. Downside business risk is reduced by implementing commodity linked credits. This is achieved because when sales decreases due to decline in milk price, the imbedded option is triggered and option payouts are counted as revenues and mitigate the downside risks; 
2. Financial risk is reduced through implementing commodity linked credits. Financial risks in this paper are measured by debt coverage ratio. The imbedded option pays out more to cover debt repayment as debt coverage ratio falls further below one, reduce the debt paid by dairy farmers;

3. Total risk, measured by the variance in return on equity, is reduced with commodity linked credits.

4. The variance in net income is reduced by commodity linked credits. Also, the expected value of net income for base model and commodity linked operating loan is converging with enough iteration; for commodity linked mortgage, the expected value of net income differ from that of base model by the difference in principal payments between base model and commodity linked mortgage;

5. The downside protection is most effective by setting the strike price of imbedded option above $80 \%$ of spot price. Below $80 \%$ of spot price, the strike price is so low that only the most extreme downside risk is reduced and the overall protection is not significant;

6. Expanding the herd size does not affect the effectiveness of commodity linked credit because constant scale of technology and the commodity linked credit is independent of herd size.

Future research could be focused on implementing a joint options hedging the milk price and feed cost risks; construct methods to pricing imbedded options in commodity linked operating loan once a year to reduce agency cost. 


\section{APPENDIX}

1. Snapshot of option calculator used to compute implied volatilities of corn and soybean price

\section{IVolatility Services}

$\checkmark \mathrm{IV}$ Index $>$ Options Calculator $\gg$ Strategist Scanners $\gg$ Volatility Ranker $\gg$ Advanced Options $\triangleright$ Spread Scanner

The IVolatility.com Options Calculator is an educational tool intended to assist individuals in learning how options work. It is not intended to provide

investment advice, and users of the Options Calculator should not make investment decisions based upon values generated by it.

\section{Symbal: $\quad$ () stock or Index Symbol O Option symbol Gol}

Today's date: 06/10/2010

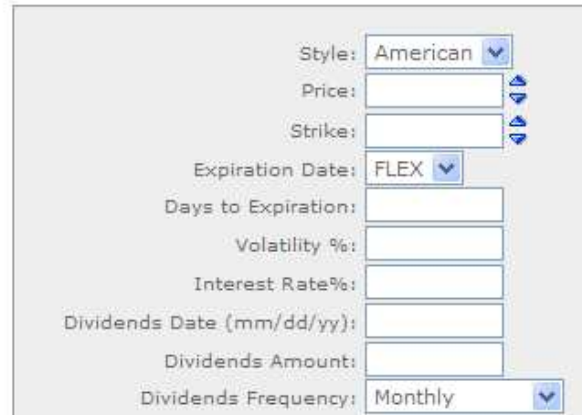

Calculate

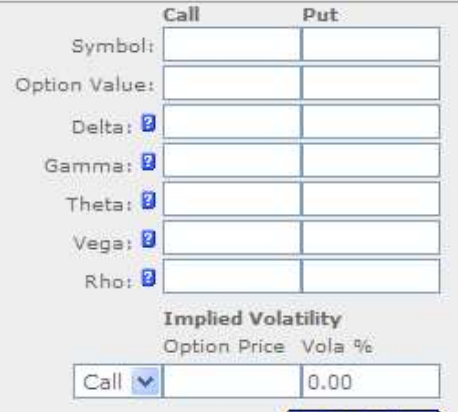

Calculate

Copyright(C) 2004 IVolatility.com All rights reserved. IVolatility Disclaimer applies.

\section{Figure 28 CBOE Implied Volatility Calculator}


2. Class III milk futures prices, calculated class III milk prices and New York State all milk prices

Table 12 Comparison of New York All Milk Prices, Class III Milk Futures Prices and Calculated Class III Prices

\begin{tabular}{|r|c|c|c|}
\hline Month & $\begin{array}{c}\text { NY all milk } \\
\text { price }\end{array}$ & $\begin{array}{c}\text { Class III milk } \\
\text { futures }\end{array}$ & $\begin{array}{c}\text { calculated } \\
\text { class III price }\end{array}$ \\
\hline Mar-00 & 12.5 & 9.633478 & 9.797417 \\
\hline Apr-00 & 12.6 & 9.503158 & 9.734532 \\
\hline May-00 & 12.8 & 14.71818 & 9.803501 \\
\hline Jun-00 & 13 & 9.445455 & 9.977003 \\
\hline Jul-00 & 13.2 & 10.6275 & 11.00699 \\
\hline Aug-00 & 13.2 & 10.18435 & 10.49948 \\
\hline Sep-00 & 13.6 & 10.7145 & 11.24263 \\
\hline Oct-00 & 13.5 & 10.08545 & 10.11149 \\
\hline Nov-00 & 13.8 & 8.816667 & 9.025974 \\
\hline Dec-00 & 13.2 & 9.2795 & 9.759602 \\
\hline Jan-01 & 14 & 9.771818 & 9.99501 \\
\hline Feb-01 & 13.9 & 10.21526 & 10.35187 \\
\hline Mar-01 & 14.8 & 11.39923 & 11.64121 \\
\hline Apr-01 & 15.4 & 11.962 & 12.45191 \\
\hline May-01 & 16.3 & 13.52182 & 14.15702 \\
\hline Jun-01 & 17 & 14.9088 & 15.38259 \\
\hline Jul-01 & 17 & 15.27619 & 15.74151 \\
\hline Aug-01 & 17.3 & 15.50407 & 15.88382 \\
\hline Sep-01 & 17.9 & 15.79056 & 16.29685 \\
\hline Oct-01 & 16.6 & 14.52957 & 14.5491 \\
\hline Nov-01 & 15.2 & 11.45095 & 11.34421 \\
\hline Dec-01 & 14 & 11.721 & 11.78459 \\
\hline Jan-02 & 14.3 & 11.83619 & 11.88876 \\
\hline Feb-02 & 13.8 & 11.69632 & 10.61305 \\
\hline Mar-02 & 13.4 & 10.618 & 10.76007 \\
\hline Apr-02 & 13.2 & 10.88389 & 10.61704 \\
\hline May-02 & 12.9 & 10.82 & 9.916421 \\
\hline Jun-02 & 12.1 & 10.2145 & 9.186488 \\
\hline Jul-02 & 11.8 & 9.469615 & 9.440997 \\
\hline Aug-02 & 11.9 & 9.552727 & 9.69054 \\
\hline Sep-02 & 12 & 9.8645 & 10.52141 \\
\hline Oct-02 & 12.5 & 10.54609 & 9.662274 \\
\hline Nov-02 & 12.7 & 9.797391 & 9.683531 \\
\hline & & & \\
\hline
\end{tabular}




\begin{tabular}{|c|c|c|c|}
\hline Dec-02 & 12.5 & 9.816191 & 9.67159 \\
\hline Jan-03 & 12.5 & 9.764286 & 9.551448 \\
\hline Feb-03 & 12.1 & 9.57 & 9.022566 \\
\hline Mar-03 & 11.7 & 9.11 & 9.227836 \\
\hline Apr-03 & 11.8 & 9.370952 & 9.546635 \\
\hline May-03 & 11.8 & 9.740833 & 9.594647 \\
\hline Jun-03 & 11.8 & 9.746191 & 11.57125 \\
\hline Jul-03 & 12.3 & 11.62227 & 13.63382 \\
\hline Aug-03 & 13.6 & 13.82048 & 14.1307 \\
\hline Sep-03 & 14.9 & 14.16238 & 14.21125 \\
\hline Oct-03 & 15.4 & 14.29826 & 13.27797 \\
\hline Nov-03 & 15.1 & 13.33722 & 11.72214 \\
\hline Dec-03 & 14.7 & 12.16571 & 11.42885 \\
\hline Jan-04 & 14 & 11.61722 & 11.42885 \\
\hline Feb-04 & 14.3 & 11.79211 & 11.79407 \\
\hline Mar-04 & 15.9 & 13.58857 & 14.32184 \\
\hline Apr-04 & 17.4 & 19.05048 & 19.45332 \\
\hline May-04 & 20.2 & 20.4075 & 20.39765 \\
\hline Jun-04 & 19.5 & 18.15905 & 17.52813 \\
\hline Jul-04 & 17.5 & 14.90381 & 14.47707 \\
\hline Aug-04 & 15.6 & 14.06273 & 13.98494 \\
\hline Sep-04 & 16.2 & 14.57857 & 14.53712 \\
\hline Oct-04 & 16.6 & 14.08333 & 13.98964 \\
\hline Nov-04 & 17 & 14.6685 & 14.76913 \\
\hline Dec-04 & 17.2 & 16.00318 & 16.00106 \\
\hline Jan-05 & 16.8 & 13.9885 & 13.99751 \\
\hline Feb-05 & 16 & 14.69391 & 14.56126 \\
\hline Mar-05 & 16.5 & 14.16591 & 13.91372 \\
\hline Apr-05 & 15.7 & 14.55905 & 14.38585 \\
\hline May-05 & 15.4 & 13.68143 & 13.4804 \\
\hline Jun-05 & 14.9 & 13.915 & 13.76355 \\
\hline Jul-05 & 15.4 & 14.3795 & 14.18312 \\
\hline Aug-05 & 15.6 & 13.70174 & 13.43493 \\
\hline Sep-05 & 16 & 14.21524 & 14.11416 \\
\hline Oct-05 & 16.3 & 14.35429 & 14.18938 \\
\hline Nov-05 & 16.1 & 13.5476 & 13.17125 \\
\hline Dec-05 & 15.7 & 13.38952 & 13.28669 \\
\hline Jan-06 & 14.8 & 13.368 & 13.13361 \\
\hline Feb-06 & 14.3 & 12.4 & 12.03101 \\
\hline Mar-06 & 13.4 & 11.26652 & 10.9441 \\
\hline
\end{tabular}




\begin{tabular}{|c|c|c|c|}
\hline Apr-06 & 12.5 & 10.92111 & 10.76106 \\
\hline May-06 & 12.4 & 10.83046 & 10.67936 \\
\hline Jun-06 & 12.3 & 11.24091 & 11.12699 \\
\hline Jul-06 & 12.3 & 11.0025 & 10.75749 \\
\hline Aug-06 & 12.5 & 11.00391 & 10.91502 \\
\hline Sep-06 & 13.2 & 12.277 & 12.16769 \\
\hline Oct-06 & 14.1 & 12.33864 & 12.09344 \\
\hline Nov-06 & 14.4 & 12.74524 & 12.71315 \\
\hline Dec-06 & 14.5 & 13.4535 & 13.29082 \\
\hline Jan-07 & 14.8 & 13.46667 & 13.37368 \\
\hline Feb-07 & 15.3 & 14.19263 & 14.23757 \\
\hline Mar-07 & 16.1 & 14.87591 & 15.19408 \\
\hline Apr-07 & 17 & 15.98095 & 16.17402 \\
\hline May-07 & 18.5 & 17.27923 & 17.70922 \\
\hline Jun-07 & 20.3 & 19.99429 & 20.59355 \\
\hline Jul-07 & 22.1 & 21.21571 & 21.36768 \\
\hline Aug-07 & 22.7 & 20.03391 & 20.05948 \\
\hline Sep-07 & 22.8 & 20.21526 & 20.17998 \\
\hline Oct-07 & 22.4 & 18.8413 & 18.81102 \\
\hline Nov-07 & 22.5 & 19.114 & 19.32856 \\
\hline Dec-07 & 22.3 & 20.3825 & 20.67668 \\
\hline Jan-08 & 21.3 & 19.52391 & 19.4712 \\
\hline Feb-08 & 19.5 & 17.4712 & 17.17099 \\
\hline Mar-08 & 18 & 18.0255 & 18.12554 \\
\hline Apr-08 & 18.2 & 16.92885 & 16.87012 \\
\hline May-08 & 17.9 & 18.03143 & 18.64271 \\
\hline Jun-08 & 18.9 & 20.16857 & 20.46554 \\
\hline Jul-08 & 20 & 18.35591 & 18.40083 \\
\hline Aug-08 & 19.1 & 17.39048 & 17.43972 \\
\hline Sep-08 & 19 & 16.43333 & 16.40518 \\
\hline Oct-08 & 17.8 & 16.85174 & 17.50407 \\
\hline Nov-08 & 17.4 & 15.46211 & 16.00714 \\
\hline Dec-08 & 16.1 & 15.24046 & 15.58442 \\
\hline Jan-09 & 15 & 10.6996 & 10.95787 \\
\hline Feb-09 & 12.5 & 9.48875 & 10.0431 \\
\hline Mar-09 & 12.2 & 10.35864 & 10.95657 \\
\hline Apr-09 & 12.7 & 10.73546 & 11.23007 \\
\hline May-09 & 12.7 & 9.8655 & 10.29776 \\
\hline Jun-09 & 12.4 & 9.895 & 10.42664 \\
\hline Jul-09 & 12.2 & 9.961364 & 10.41042 \\
\hline
\end{tabular}




\begin{tabular}{|c|c|c|c|}
\hline Aug-09 & 12.7 & 11.13714 & 11.63006 \\
\hline Sep-09 & 13.5 & 11.9 & 12.56431 \\
\hline Oct-09 & 15 & 12.71046 & 13.44001 \\
\hline Nov-09 & 16 & 14.024 & 14.63671 \\
\hline Dec-09 & 17.1 & 14.70318 & 15.43559 \\
\hline Jan-10 & 16.8 & 14.39579 & 14.93969 \\
\hline Feb-10 & 16.8 & 14.29053 & 14.72863 \\
\hline Mar-10 & 16.1 & 13.10071 & 13.24398 \\
\hline
\end{tabular}




\section{REFERENCES}

Black, F. and Scholes, M., 1973, "the pricing of options and corporate liabilities", Journal of Political Economy, Vol.81, pp.637-659

Binswanger, H.P., 1981, "Attitudes toward Risk: Theoretical Implications of an Experiment in Rural India", The Economic Journal, Vol.91, No.364, pp.867-890

Briggeman, B.C., Towe, C.A., and Morehart, M.J., 2009, “Credit Constraints: Their Existence, Determinants, and Implications for U.S. Farm and Nonfarm Sole Proprietorships", American Journal of Agricultural Economics, Vol. 91, No.1, pp.275289

Center for Dairy Profitability, 'Dairy Proforma Calculator', University of WisconsinMadison, http://cdp.wisc.edu/Decision\%20Making\%20Tools.htm

Collins, R.A., 1985, "Expected Utility, Debt-Equity Structure and Risk Balancing”, American Journal of Agricultural Economics, Vol. 67, No.3, pp. 627-629

Definition of Net Income, Put Option, Geometric Brownian Motion, http://www.wikipedia.org/

Gould, B., "Understanding Dairy Market”, University of Wisconsin-Madison, http://future.aae.wisc.edu/index.html

Jesse, E. and Cropp, B., 2008, "Basic Milk Pricing Concepts for Dairy Farmers", Department of Agriculture, University of Wisconsin-Extension, Cooperative Extension

Jin, Y. and Turvey, C.G., 2002, "Hedging Financial and Business Risks in Agriculture with Commodity Linked Loan”, Vlo.62, No.1,pp.41

Knoblauch, W.A., Putnam, L.D., Karszes, J. and Anderson, J., 2009, "Dairy Farm Management Business Summary New York State 2008”, Department of Applied Economics and Management

Knoblauch, W.A., Putnam, L.D., Karszes, J. and Anderson, J., 2008, "Dairy Farm Management Business Summary New York State 2007”, Department of Applied Economics and Management

Knoblauch, W.A., Putnam, L.D., Karszes, J., Murray D. and Moag R., 2007, "Dairy Farm Management Business Summary New York State 2006", Department of Applied Economics and Management 
Knoblauch, W.A., Putnam, L.D., Karszes, J., 2006, "Dairy Farm Management Business Summary New York State 2005", Department of Applied Economics and Management

Knoblauch, W.A., Putnam, L.D., Karszes, J., 2005, "Dairy Farm Management Business Summary New York State 2004", Department of Applied Economics and Management

LaDue, E.L., 2002, "Projecting Cash Flows on Dairy Farms", Agricultural Finance and Management at Cornell

National Agricultural Statistics Service, http://www.nass.usda.gov

Schwartz, E.S., 1982, "The Pricing of Commodity-Linked Bonds", The Journal Of Finance, Vol. 37, No. 2, pp. 525-539

Schwartz, E.S., 1997, "The Stochastic Behavior of Commodity Prices: Implications for Valuation and Hedging", The Journal of Finance, Vol. 52, No. 3, pp. 923-973

Tagliani, M., "The Practical Guide to Wall Street Equities and Derivatives", John Wiley \& Sons, Inc., Hoboken, New Jersey

Turvey, C.G., 2006, "Managing Food Industry Business and Financial Risks with Commodity-Linked Credit Instruments", Agribusiness, Vol.22, No. 1, pp.523-545

Turvey, C.G.and Baker, T.G., 1991, "Optimal Hedging Under Alternative Capital Structures and Risk Aversion", Canadian Journal of Agricultural Economics, Vol.31, No.3, pp.135-143

Turvey, C.G.and Shee, A., 2008, "Collateral Free Lending with Risk-Contingent Credit for Agricultural Development", working paper 